\title{
11. RADIOLARIANS FROM THE MIDDLE AMERICA TRENCH OFF GUATEMALA, DEEP SEA DRILLING PROJECT LEG 671
}

\author{
M. J. Westberg and W. R. Riedel, Geological Research Division, Scripps Institution of Oceanography, \\ University of California, San Diego, La Jolla, California
}

\begin{abstract}
Radiolarians were found at all Leg 67 sites. At oceanic reference Site 495 and Trench floor Sites 499 and 500, radiolarian sequences from the lower Miocene Stichocorys delmontensis Zone through the Quaternary were recovered. Four sites were located on the inner Trench slope: at Sites 496 and 498, drilling penetrated to the Calocycletta costata Zone of the early Miocene, at Site 497 only Quaternary and Pliocene material was recovered, and at Site 494, the Cretaceous was reached. An index of reliability is described and used to resolve conflicts in radiolarian correlations of the seven sites. The composition of assemblages is described in terms of relative abundances of radiolarian families, and these data are used as a basis for comparing margin and open-ocean sites.
\end{abstract}

\section{INTRODUCTION}

Radiolarians were recovered at all seven Leg 67 sites located on a transect of the Middle America Trench off Guatemala. Oceanic reference Site 495 is on the Cocos Plate, $22 \mathrm{~km}$ seaward of the Trench axis; Sites 499 and 500 are on the Trench floor; and Sites 494, 496, 497, and 498 are on the inner Trench wall. The localities and water depths of the sites are:

Site $494,12^{\circ} 43.01^{\prime} \mathrm{N}, 90^{\circ} 55.97^{\prime} \mathrm{W}, 5529$ meters

Site $495,12^{\circ} 29.78^{\prime} \mathrm{N}, 91^{\circ} 02.26^{\prime} \mathrm{W}, 4150$ meters

Site $496,13^{\circ} 03.82^{\prime} \mathrm{N}, 90^{\circ} 47.71^{\prime} \mathrm{W}, 2064$ meters

Site $497,12^{\circ} 59.23^{\prime} \mathrm{N}, 90^{\circ} 49.68^{\prime} \mathrm{W}, 2358$ meters

Site $498,12^{\circ} 42.68^{\prime} \mathrm{N}, 90^{\circ} 54.94^{\prime} \mathrm{W}, 5497$ meters

Site $499,12^{\circ} 40.23^{\prime} \mathrm{N}, 90^{\circ} 56.65^{\prime} \mathrm{W}, 6127$ meters

Site $500,12^{\circ} 41.16^{\prime} \mathrm{N}, 90^{\circ} 56.58^{\prime} \mathrm{W}, 6127$ meters

Radiolarian assemblages range from lower Miocene to Quaternary at Sites $495,496,498,499$, and 500 and from Pliocene to Quaternary at Site 497 . Site 494 contains a Pliocene to Quaternary sequence from Cores 1 to 20, rare lower Miocene forms in Cores 20 to 22, a middle Eocene assemblage in Cores 23 to 27, and rare Cretaceous and Eocene forms in Cores 28 and 29. Figure 1 is a synopsis of radiolarian zones represented in Leg 67 sites.

In many of the Quaternary and Pliocene samples, and in Miocene slope sediments, radiolarian assemblages are diluted by clay aggregates, ash, diatoms, or terrigenous minerals.

\section{PROCEDURES}

Generally, we took two or three samples per core, but rapidly accumulated sediments were sampled at longer intervals. Sediments were sieved at $44 \mu \mathrm{m}$ and strewn slides prepared in our standard manner.

Relative abundances of species are recorded in two ways. First, in the main part of ranges and at most morphotypic limits, five grades of abundance indicate the percentage that a taxon represents of the total assemblage on the strewn slide. These abundance grades are explained

\footnotetext{
${ }^{1}$ Aubouin, J., von Huene, R., et al., Init. Repts. DSDP, 67: Washington (U.S. Govt. Printing Office).
}

in the note to Table 1. Second, near evolutionary transitions, "constant-numerator" percentage estimates were used. The density of radiolarians on a slide having been estimated, this density is then used to estimate the number of radiolarians in a counted number of fields that must be searched to find 10 specimens of a taxon (Riedel and Sanfilippo, 1978a).

Relative abundance data for radiolarian families are recorded in a third way. At least 300 radiolarians per slide were categorized in 15 families, and percentages calculated and rounded to the nearest whole number. The family abundance tables also include an estimate of the proportion of each field covered by diluting components such as diatoms, volcanic ash, or terrigenous debris.

The radiolarian zones used in this paper for the Tertiary are the chronozones defined by Riedel and Sanfilippo (1978b). The Quaternary zones are those defined by Nigrini (1971).

\section{SITE 494}

Site 494 was drilled on a small terrace of the lower Trench slope. The Holocene to Pliocene, dark gray, diatomaceous mud of Cores 494-1 through 494A-20 contains radiolarian assemblages of moderate preservation, but often highly diluted by clay aggregates, diatoms, or ash. Because of the sparseness of the fauna and missing index species, the Quaternary zones cannot be determined. The latest occurrence of Axoprunum angelinum is between Samples 494A-2-6, 29-31 cm and 494A-4-1, $1-3 \mathrm{~cm}$. According to Hays et al. (Stylatractus sp., 1969) and Johnson and Knoll (1975), this species became extinct about 320,000 to 400,000 years ago. The top of the Spongaster pentas Zone, indicated by the morphotypic top of Stichocorys peregrina, is between Samples 494A$17-2,64-66 \mathrm{~cm}$ and $494 \mathrm{~A}-18-1,90-92 \mathrm{~cm}$. Blue clasts with middle Miocene species occur throughout the section. Occasionally, Eocene species are reworked into these younger sediments. Relative abundances of Pliocene and younger taxa found in these cores are recorded in Table 1.

The blue gray hemipelagic clays of Sections 494A20-4 to 494A-22-3 contain radiolarians in two different preservational states. There are moderately well-preserved specimens of Calocycletta virginis, Eucyrtidium diaphanes, Stichocorys delmontensis, Theocorys spon- 


\begin{tabular}{|c|c|c|c|c|c|c|c|c|}
\hline Epoch & Radiolarian Zone & 495 & 499 & 500 & 498 & 494 & 497 & 496 \\
\hline \multirow{3}{*}{ 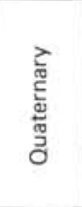 } & C. tuberosa & & $2-2$ & \multirow{3}{*}{$\begin{array}{l}1-1 \\
10-2 \\
A 1, C C \\
A 2, C C\end{array}$} & $\begin{array}{l}1.1 \\
1.3\end{array}$ & \multirow{4}{*}{$\begin{array}{l}1-1 \\
4 \cdot 4 \\
\& \\
\text { A } 1.1 \\
\text { A } 17.2\end{array}$} & $1-3$ & $1-1$ \\
\hline & A. ypsilon & $\begin{array}{l}3-1 \\
3-6\end{array}$ & $\begin{array}{r}3.4 \\
17.5\end{array}$ & & $\begin{array}{c}2.1 \\
\mathrm{~A} 2, \mathrm{CC} \\
\mathrm{A} 3, \mathrm{CC}\end{array}$ & & $\begin{array}{r}2-3 \\
13-4\end{array}$ & $\begin{array}{r}1.5 \\
21.6\end{array}$ \\
\hline & A. angulare & $\begin{array}{l}4.1 \\
7.1\end{array}$ & $\begin{array}{l}18 \cdot 1 \\
19 \cdot 3\end{array}$ & & & & $\begin{array}{l}15.4 \\
18.5\end{array}$ & $\begin{array}{l}22.4 \\
23.6\end{array}$ \\
\hline \multirow{2}{*}{ 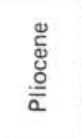 } & P. prismatium & $\begin{array}{l}7.3 \\
9-3\end{array}$ & $\begin{array}{l}19.6 \\
22.6\end{array}$ & & $\begin{array}{l}\text { ?A8-7 } \\
\text { ?A9,CC }\end{array}$ & & $\begin{array}{l}19.2 \\
25.4\end{array}$ & $\begin{array}{l}24-3 \\
26-4\end{array}$ \\
\hline & S. pentas & $\begin{array}{r}9.6 \\
15.5\end{array}$ & & & & $\begin{array}{l}\text { A } 18-1 \\
\text { A20-3 }\end{array}$ & $\begin{array}{l}26-3 \\
42-7\end{array}$ & $\begin{array}{l}27.4 \\
28.3\end{array}$ \\
\hline \multirow{3}{*}{ 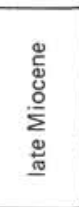 } & S. peregrina & & & & $\begin{array}{l}\text { A7-1 } \\
\text { ?A 12-1 }\end{array}$ & & Gas & $\begin{array}{l}28-4 \\
28-5\end{array}$ \\
\hline & D. penultima & $\begin{array}{l}16 \cdot 2 \\
16.6\end{array}$ & & & & & & \\
\hline & D. antepenu/tima & $\begin{array}{l}17.1 \\
17.6\end{array}$ & $\begin{array}{l}23-1 \& \& \\
\text { B1,CC }\end{array}$ & & & & & \\
\hline \multirow{2}{*}{ 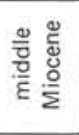 } & D. petterssoni & $\begin{array}{l}18-2 \\
19-6\end{array}$ & & & A7.4 & & & $29 \cdot 3$ \\
\hline & D. alata & $\begin{array}{l}20-1 \\
23-6\end{array}$ & $\begin{array}{l}23.1 \\
23, \mathrm{CC} \\
\mathrm{B} 1, \mathrm{CC}\end{array}$ & $\begin{array}{l}10-2 \\
10-3\end{array}$ & $\longdiv { 4 0 }$ & & & $30-2$ \\
\hline \multirow{4}{*}{ 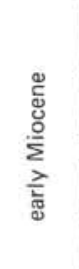 } & C. costata & $\begin{array}{l}24-1 \\
29-5 \\
\end{array}$ & $\begin{array}{l}24-1 \\
25-3 \\
\text { B } 1, \mathrm{CC}\end{array}$ & $\begin{array}{l}11.3 \\
11.4 \\
\end{array}$ & $\begin{array}{r}\text { A } 10.1 \\
\text { ?A } 13.1 \\
\text { A } 15-2\end{array}$ & & & $\begin{array}{l}35-2 \\
40-1 \\
\end{array}$ \\
\hline & S. wolffii & $\begin{array}{l}30-1 \\
32-2\end{array}$ & $\begin{array}{l}25.4 \& \\
B 3.4\end{array}$ & $12-3$ & Gas & & & Gas \\
\hline & S. delmontensis & $\begin{array}{l}32.5 \\
37.3\end{array}$ & $\begin{array}{l}\text { B4-1 } \\
\text { B6-1 }\end{array}$ & $\begin{array}{l}13.3 \\
14.4\end{array}$ & & & & \\
\hline & C. tetrapera & & & & & \multirow{2}{*}{$\begin{array}{l}\text { A20-4 } \\
\text { A22-3 }\end{array}$} & & \\
\hline $\begin{array}{l}\text { Oligo- } \\
\text { cene }\end{array}$ & L. elongata & & & & & & & \\
\hline Eocene & P. mitra & & & & & $\begin{array}{l}\text { A } 23-1 \\
\text { A } 27-2\end{array}$ & & \\
\hline $\begin{array}{l}\text { Creta- } \\
\text { ceous }\end{array}$ & & & & & & $\begin{array}{l}\text { A } 28.1 \\
\text { A29.2 }\end{array}$ & & \\
\hline
\end{tabular}

Figure 1. Radiolarian zones represented in Leg 67 sites. (Sites are ordered from west to east. Cores and sections from each hole are shown.)

goconus, and Carpocanopsis cingulata. Occurring with these are poorly preserved, probably calcitized specimens of C. virginis, Artophormis gracilis, and Theocyrtis annosa. These latter could be reworked from the late Oligocene or early Miocene. Samples 494A-22-3, 91-93 cm and 102-104 cm contain none of the altered forms, but have an assemblage made up largely of fragmented spongodiscids with rare occurrences of Stichocorys wolffii, S. peregrina, and Phormostichoartus corbula.

Dark gray mudstones in Cores 494A-23 through 494A27 contain rare to common middle Eocene radiolarians, poorly preserved due to dissolution and fragmentation. The assemblage is probably from the Podocyrtis mitra Zone, and includes Lithocyclia ocellus, Calocyclas hispida, Eusyringium fistuligerum, Lithochytris vespertilio, Sethochytris triconiscus, Theocotyle cryptocephala, Thyrsocyrtis (Thyrsocyrtis) rhizodon, T. (Pentalocorys) triacantha, Podocyrtis papalis, P. mitra, Dictyoprora amphora, D. mongolfieri, and D. urceolus.

The mudstones of Cores 494A-28 and 494A-29 contain both Eocene and Cretaceous forms. The dark olive gray sediment of Sample 494A-29-1, 14-16 cm includes many of the Eocene forms just listed. The light gray mud of Sample 494-29-1, 100-102 cm contains common, poorly preserved, altered radiolarians deposited in the Late Cretaceous: Amphipyndax stocki, Dictyomitra koslovae, Dictyomitra spp., Eucyrtis micropora, and Alievium superbum. Very rare occurrences of the Eocene species Dictyoprora mongolfieri and Lophocyrtis biaurita are from small dark chips of Eocene mudstone mixed by the drilling operation into the lighter Cretaceous sediments. Sample 494A-29-1, 135-137 cm contains several fragments of what appear to be the Eocene genus Podocyrtis, and rare, very poorly preserved Upper Cretaceous Dictyomitra spp. Sample 494A-29-2, $30-32 \mathrm{~cm}$ repeats this same mixture of predominantly Upper Cretaceous radiolarians with a minor component of Eocene forms.

No radiolarians were found below Core 494A-29.

\section{SITE 495}

Site 495 was drilled for an oceanic reference site on the oceanic crust seaward of the Trench axis. Tertiary movements of the Cocos Plate apparently caused the transitions from early Miocene carbonate-rich sedi- 
Table 1. Abundances of some radiolarians at Site 494 .

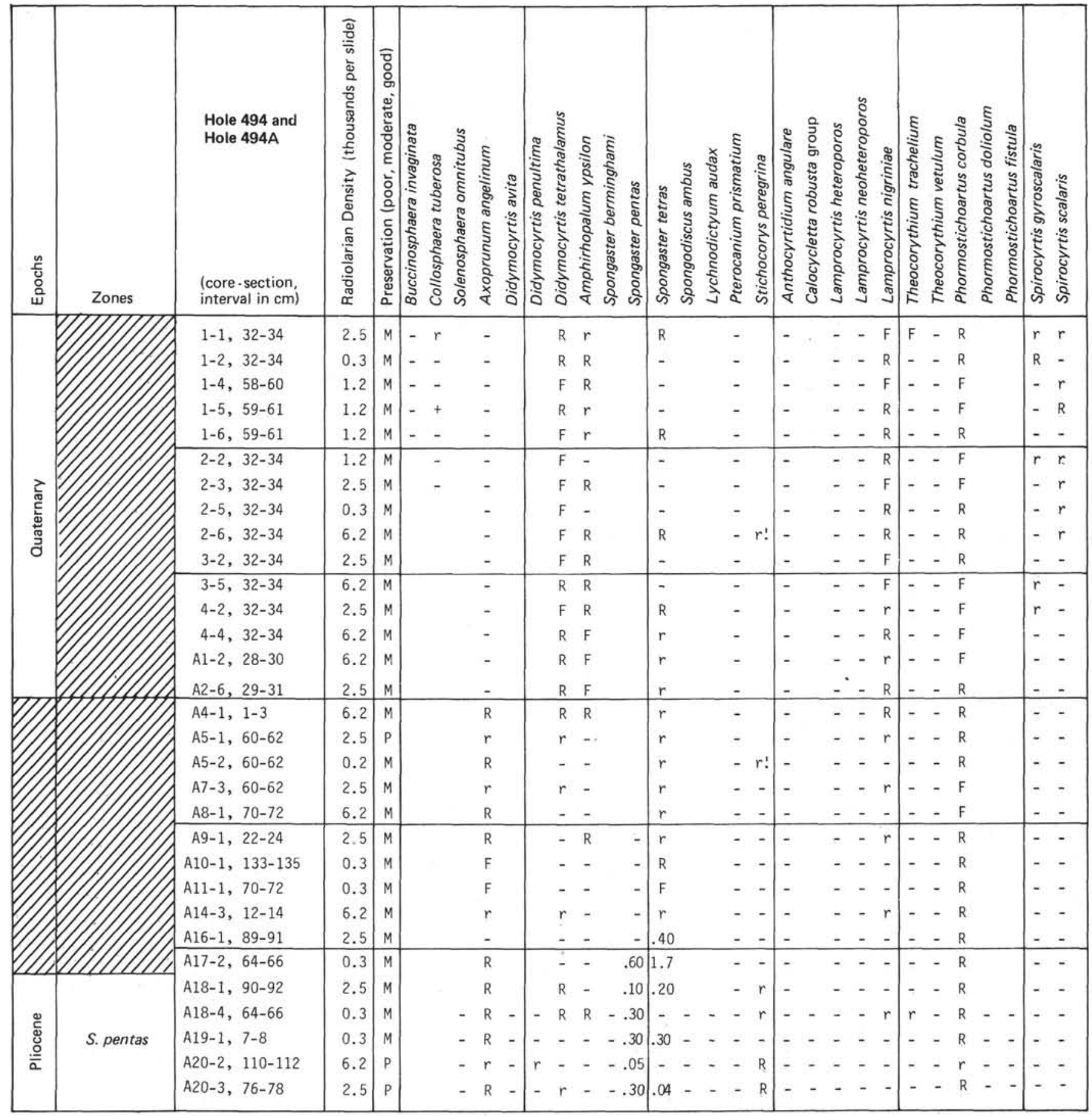

Note: In the body of the table - indicates that the species was sought but not found; + indicates $<0.01 \%$ of the radiolarians on the slide; $r$, very rare, $0.01-0.1 \%$; $R$, rare, $0.1-1 \% ; F$, few, 1-10\%; ! indicates reworking; $\langle$ and $>$ are used to indicate the dominant taxon when an ancestor's and descendant's abundance falls in the same percentage range. At critical parts of ranges, numbers indicate abundances in percentage of total radiolarians on the slide as determined by constant numerator counts (see text).

ments with high accumulation rates to middle Miocene radiolarian-rich red clays to hemipelagic muds of the Pliocene and Pleistocene.

The first 37 of 49 cores drilled contain typical lowlatitude radiolarian assemblages. The upper 171 meters, Cores 495-1 through -18, are a hemipelagic, green and olive gray mud. Assemblages are occasionally diluted by terrigenous components or diatoms, but for the most part, radiolarians are common and well to moderately well preserved.

Species indicative of the upper two Quaternary zones are absent at Site 495 , and the first samples contain Axoprunum angelinum, indicating an age of at least 320,000 to 400,000 years. Core $495-3$ is placed in the 
Amphirhopalum ypsilon Zone by the absence of Anthocyrtidium angulare. Very rare occurrences of $A$. angulare in Cores 495-4 through -6 indicate the lowest Quaternary $A$. angulare Zone. The Pliocene/Pleistocene boundary, and the top of the Pterocanium prismatium Zone, is placed between Samples 495-7-1, 70-72 cm and 495-7-3, 70-72 $\mathrm{cm}$ by the latest occurrence of $P$. prismatium. This designation, however, is tenuous because of the extreme rarity of $P$. prismatium and $A$. angulare.

The latest occurrence of Stichocorys peregrina between Samples 495-9-3, 75-77 cm and 495-9-6, 26-28 cm marks the bottom of the $P$. prismatium Zone.

The events indicating the bottoms of the Spongaster pentas and Stichocorys peregrina Zones, namely the evolutionary transitions between Spongaster berminghami and S. pentas and between Stichocorys delmontensis and $S$. peregrina, respectively, occur in the same interval between Samples 495-16-2, 30-32 cm and 495$15-5,30-32 \mathrm{~cm}$, suggesting that the $S$. peregrina Zone is compressed and not sampled. This conclusion is supported by the latest occurrence of the Calocycletta robusta group in that same interval, an event known to occur in the $S$. peregrina Zone.

The bottom of the Didymocyrtis penultima Zone is indicated by the latest occurrence of Diartus hughesi between Samples 495-16-6, 30-32 cm and 495-17-1, 30$32 \mathrm{~cm}$. The Didymocyrtis antepenultima Zone extends from that interval down to the transition of Diartus petterssoni to $D$. hughesi between Samples 495-18-2, 90-92 $\mathrm{cm}$ and $495-17-6,30-32 \mathrm{~cm}$. Relative abundances of late Miocene to Quaternary radiolarians at Site 495 are recorded in Table 2.

The muds of Core 495-18 and the carbonate-poor red clay of Core 495-19 belong to the middle Miocene $D$. petterssoni Zone. The earliest occurrence of $D$. petterssoni marks the bottom of this zone, between Samples $495-19-6,8-10 \mathrm{~cm}$ and $495-20-1,60-62 \mathrm{~cm}$.

Cores 495-20 through -37 are chalky carbonate ooze with chert in the lower section, and they continue a complete record of middle and lower Miocene radiolarian zones. The transition of Dorcadospyris dentata to $D$. alata, between Samples 495-23-6, 40-42 cm and 495-24$1,15-17 \mathrm{~cm}$, indicates the bottom of the $D$. alata Zone. The earliest occurrence of Calocycletta costata, between Samples 495-29-5, 19-21 cm and 495-30-1, 30-32 cm, marks the bottom of the $C$. costata Zone. The morphotypic bottom of Stichocorys wolffii marks the bottom of the S. wolffii Zone, between Samples 495-32-2, 39$41 \mathrm{~cm}$ and $495-32-5,39-41 \mathrm{~cm}$. The remaining cores through 495-37-3 belong to the Stichocorys delmontensis Zone. Unusually low occurrences of Lithopera renzae, S. wolfii, Phormostichoartus corbula, and Siphostichoartus corona in abundances of $<0.1 \%$ suggest downworking between Cores 495-26 through -36. Samples taken from Cores $495-38$ through -43 and -46 were all barren of radiolarians. Table 3 records abundances of early to middle Miocene radiolarians at Site 495 .

\section{SITE 496}

At midslope Site 496, the objective was to penetrate a landward-dipping seismic reflector, but drilling was ter- minated short of this goal because of recovery of gaseous hydrocarbons. The upper 226 meters of Hole 496 are biogenic mud, but the well-preserved Quaternary radiolarians are diluted by 50 to $90 \%$ terrigenous debris in the sand-size fraction.

Sample 496-1-1, 50-52 cm is assigned to the Collosphaera tuberosa Zone on the basis of the presence of that species. Between Sections 496-1-5 and 496-21-6, radiolarian assemblages belong to the Amphirhopalum ypsilon Zone. Samples 496-22-4, 65-67 cm and 496-23$6,32-34 \mathrm{~cm}$ are assigned to the Anthocyrtidium angulare Zone on the basis of very rare occurrences of $A$. angulare. The top of the Spongaster pentas Zone is placed between Samples 496-27-1, 70-72 cm and 496-27-4, $29-31 \mathrm{~cm}$ by the latest occurrence of Stichocorys peregrina. All of these zonal assignments are tenuous because of the very low numbers of index species. Relative abundances of Quaternary and Pliocene radiolarians at Site 496 are recorded in Table 4.

Samples 496-28-4, 87-89 $\mathrm{cm}$ and 496-28-5, 140-142 $\mathrm{cm}$ are assigned to the $S$. peregrina Zone because $S$. delmontensis is present, but in smaller numbers than $S$. peregrina. The upper Miocene Didymocyrtis penultima and $D$. antepenultima Zones were not observed at this site.

Samples 496-29-1, 90-92 cm and 496-29-3, 40-42 cm belong to the middle Miocene Diartus petterssoni Zone. The Dorcadospyris alata Zone is indicated in Sample 496-30-2, 45-47 $\mathrm{cm}$ by the presence of $D$. alata without $D$. dentata. Equal numbers of those two species in Core 31 , and their absence from samples from Cores 33 and 34 , prevent zonal assignments. However, all the samples taken between Sections 496-35-2 and 496-40-1 appear to be in the Calocycletta costata Zone. Relative abundances of middle Miocene radiolarians at Site 496 are recorded in Table 5.

\section{SITE 497}

Site 497 was drilled on the midslope $8 \mathrm{~km}$ seaward of Site 496 and was also terminated early because of recovery of gaseous hydrocarbons. The sediments are predominantly dark olive gray muds containing moderately well-preserved Quaternary to Pliocene radiolarian assemblages highly diluted with terrigenous components. Relative abundances of radiolarians and zonations are shown in Table 6.

\section{SITE 498}

Site 498 was drilled $1 \mathrm{~km}$ east of Site 494 on the lower slope to avoid a transverse fault and improve core recovery. Again, the hole was abandoned because of gas recovery. Most of the poorly recovered cores are drilling breccia composed of dark olive gray mudstone, with chips of blue gray Miocene mudstone. Many of the samples from Site 498 yielded too few radiolarians for stratigraphic interpretation. Reworking of Miocene and sometimes Eocene species into younger sediments is frequent throughout the entire section.

Samples $498-1-1,28-30 \mathrm{~cm}, 498-1-3,128-130 \mathrm{~cm}$, $498-2-1,30-32 \mathrm{~cm}, 498 \mathrm{~A}-2, \mathrm{CC}(14-16 \mathrm{~cm})$, and 498A$3, \mathrm{CC}(25-27 \mathrm{~cm})$ contain Quaternary radiolarians. The 
Table 2. Late Miocene to Quaternary radiolarians at Site 495.

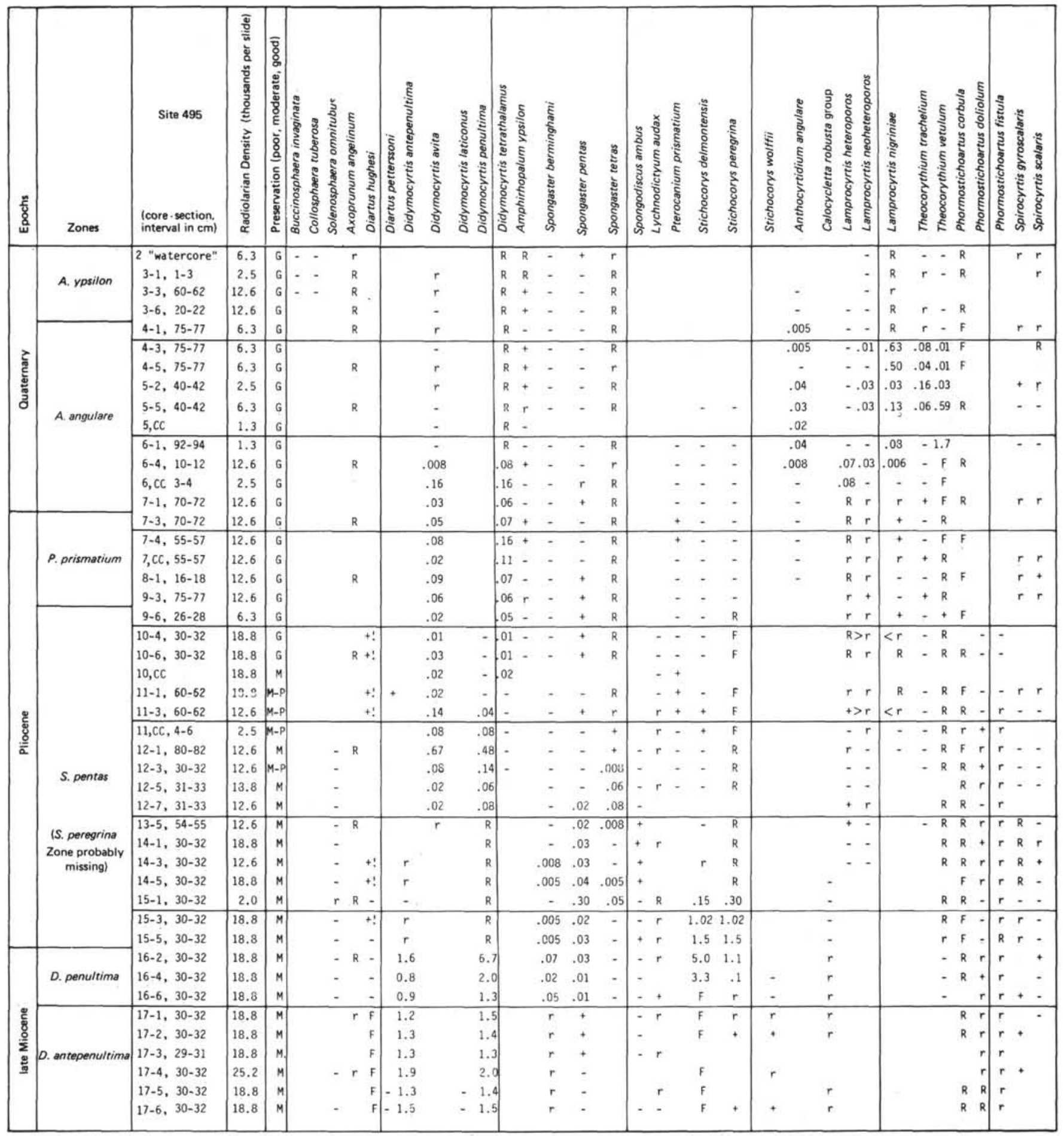

Note: Symbols as for Table 1.

first two samples are from the uppermost Quaternary, on the basis of the presence of Buccinosphaera invaginata and Collosphaera tuberosa; and the remaining three are probably older than 320,000 yrs., based on the presence of Axoprunum angelinum. Sample 498A-5-1, 80-82 cm contains about 500 specimens from the middle Miocene Diartus petterssoni and Dorcadospyris alata Zones. Sam- ple 498A-5-6, 135-137 cm contains a sparse assemblage from the Calocycletta costata Zone.

Radiolarians from Sample 498A-7-1, 40-42 cm, though sparse and poorly preserved, appear to be younger, probably from the upper Miocene Stichocorys peregrina Zone. Very rare specimens from the $D$. petterssoni Zone were found in Sample 498A-7-4, 30-32 cm. The 
Table 3. Early to middle Miocene radiolarians at Site 495 .

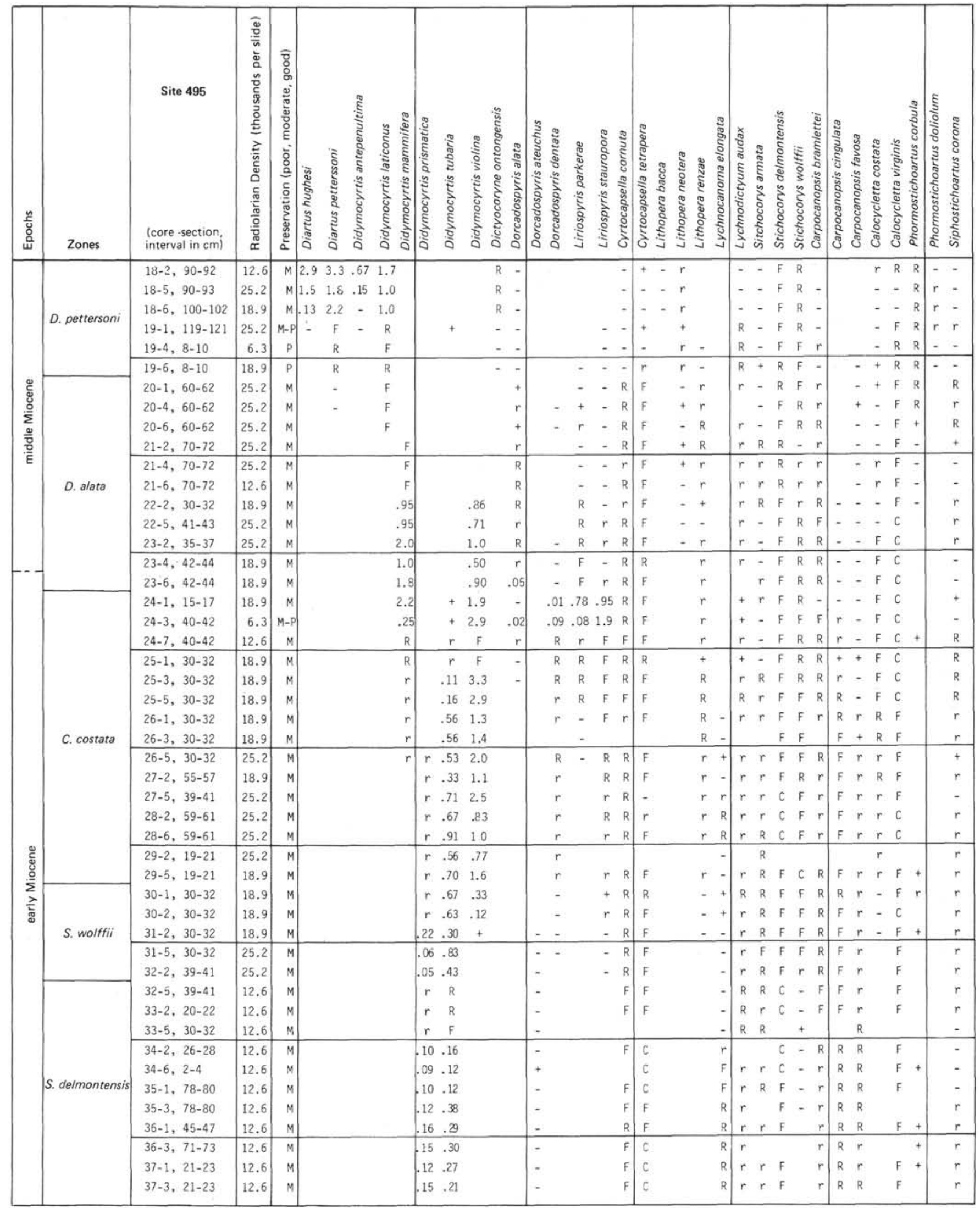

Note: Symbols as for Table 1. 
Table 4. Pliocene to Quaternary radiolarians at Site 496.

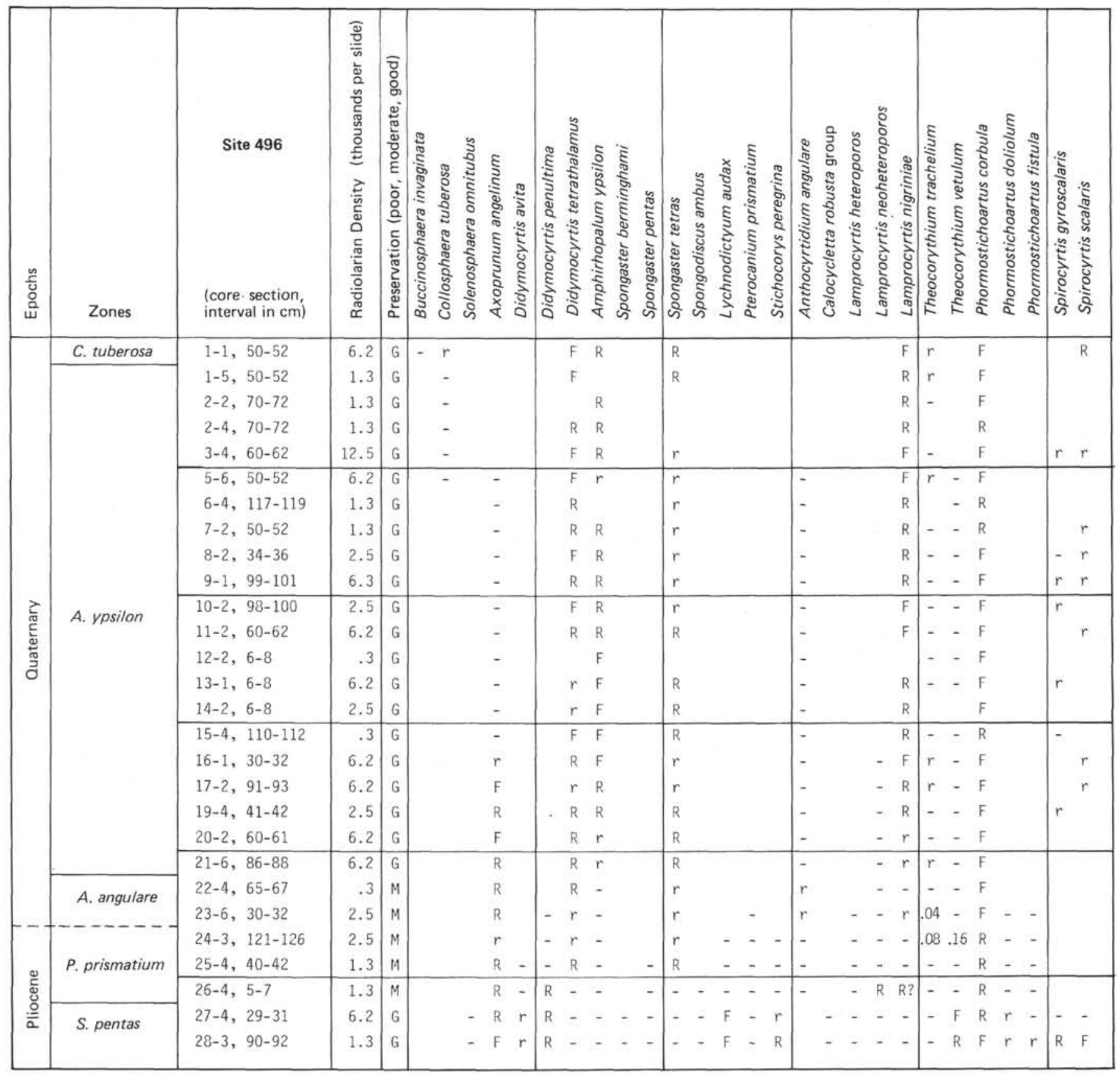

Note: Symbols as for Table 1.

presence of Didymocyrtis avita, Spongaster tetras, Stichocorys peregrina, Lamprocyrtis nigriniae, and Theocorythium trachelium in Samples 498A-8-7, 24-26 cm and 498A-9, CC suggest the Pliocene or Quaternary, although these are single occurrences in very sparse assemblages. Cores $498 \mathrm{~A}-10$ through -15 are highly disturbed drilling breccia with very little recovery. Radiolarians are extremely rare, and early Miocene through Pliocene forms are mixed.

\section{SITE 499}

Site 499 is on the Trench floor, just seaward of the Trench axis. It consists of trench-fill turbidites overlying a lithologic sequence similar to Site 495 , the oceanic reference site.

The first fourteen cores are all trench-fill turbidites, and are probably younger than 320,000 to 400,000 yrs., based on the latest occurrence of Axoprunum angelinum between Samples 499-14-3, 37-39 cm and 499-15-3, 102$103 \mathrm{~cm}$. It is not possible to place the Pliocene/Pleistocene boundary with certainty because of the absence of Pterocanium prismatium and the extremely low numbers of Lamprocyrtis heteroporos, L. neoheteroporos, Theocorythium vetulum, and $T$. trachelium. However, Anthocyrtidium angulare occurs in Cores 18 and 19, and the lower boundary of that zone is therefore tenta- 
Table 5. Middle Miocene radiolarians at Site 496.

\begin{tabular}{|c|c|c|c|c|c|c|c|c|c|c|c|c|c|c|c|c|c|c|c|c|c|c|c|c|c|c|c|c|c|}
\hline $\begin{array}{l}\frac{n}{\tilde{L}} \\
\text { జे }\end{array}$ & Zones & Site 496 & 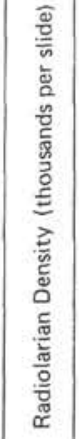 & 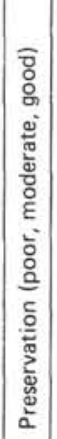 & 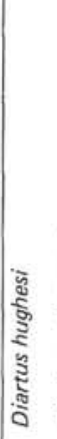 & 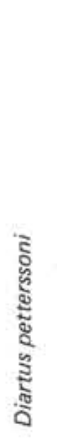 & 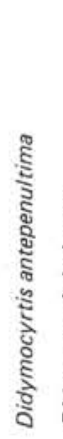 & 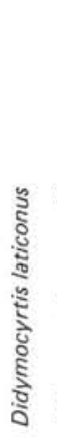 & 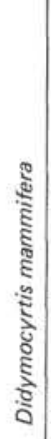 & 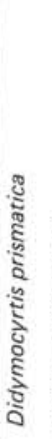 & 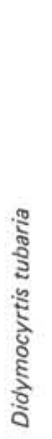 & 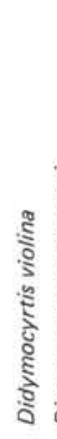 & 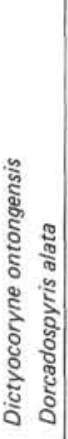 & 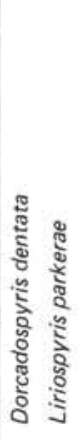 & 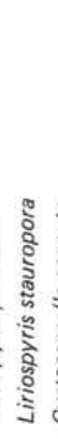 & 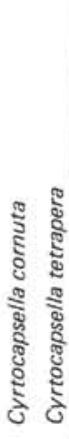 & 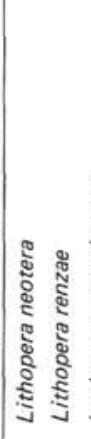 & 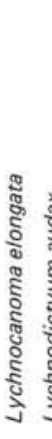 & 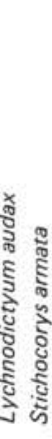 & & : & 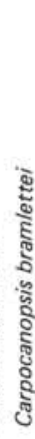 & & 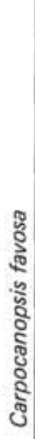 & & 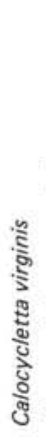 & 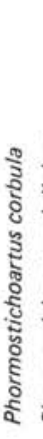 & 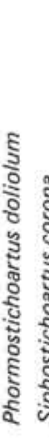 & ڤัँ \\
\hline \multirow{7}{*}{ 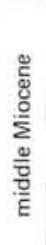 } & D. petterssoni & $29-3,40-42$ & 1.0 & $\mathrm{p}$. & .97 & 5.0 & 2.3 & 4.3 & - & & - & - & $-\quad-$ & -- & - & $-\quad-$ & - & - & - - & & R - & - & - & - & - & - & - & - & - \\
\hline & D. alata & $30-3,45-47$ & 18.5 & M & - & - & - & $F$ & - & & - & - & $-r$ & - & - & $-r$ & $r$ - & - & $r-$ & & R - & - & - & - & - & R & $R$ & - & R \\
\hline & QDVDI & $31-3,12-14$ & 6.3 & M & - & - & - & - & .06 & & .08 & .97 &.$- \infty 2$ & $.02-$ & $r$ & - & $-r$ & $-r$ & $r-$ & c & $6 \mathrm{~F}$ & r & r & - & - & $\mathrm{F}$ & - & - & - \\
\hline & 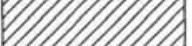 & $33-5,9-11$ & 1.0 & M & & & & & & & .20 & .60 & - & -- & $R$ & -- & - - & - & - - & c & C $c$ & r & $\mathrm{F}$ & $r$ & & c & - & - & - \\
\hline & - I I & $34-2,25-27$ & 2.5 & M & & & & & & & .36 & 1.3 & - & - & $R$ & - & - & - & - $R$ & $c$ & $c \mathrm{C}$ & $r$ & $\mathrm{R}$ & r & - & c & - & - & $r$ \\
\hline & Illlllllas & $34-5,20-22$ & .30 & M & & & & & & & & & - & - & $R$ & & & - & & c & C $\mathrm{C}$ & $R$ & & $R$ & - & & & & - \\
\hline & \multirow{8}{*}{ C. costata } & $35-2,60-62$ & 2.5 & M & & & & & & & .44 & .44 & - & R & $r$ & $r-$ & - - & - & $r-$ & $c$ & C $\mathrm{C}$ & R & R & $r$ & $\mathrm{R}$ & & & & - \\
\hline \multirow{7}{*}{ 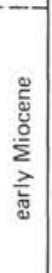 } & & $35-5,80-81$ & 6.3 & M & & & & & & & .16 & .21 & & r & R & -- & - - & - & r & c & $C F$ & r & r & - & R & c & & & - \\
\hline & & $36-2,90-92$ & 12.6 & M & & & & & & r. & .67 & .85 & & r & R & - & $r$ & - & $\mathrm{F}$ & c & C $F$ & R & & $r$ & & $\mathrm{~F}$ & & & R \\
\hline & & $36-4,50-52$ & 6.3 & M & & & & & & & .51 & .57 & & - & R & & - & - & $\mathrm{R}$ & c & $C \mathrm{~F}$ & & & & & & & & $\mathrm{R}$ \\
\hline & & $37-1,72-74$ & .50 & $M-P$ & & & & & & & .20 & .40 & & - & & & & - & $\bar{F}$ & $\bar{F}$ & $F$ & & & $r$ & & $F$ & & & - \\
\hline & & $39-1,10-12$ & .50 & $M-P$ & & & & & & .20 & .60 & 1.0 & & - & $F$ & & & - & R & c & C $c$ & R & $\mathrm{F}$ & R & R & $c$ & & & - \\
\hline & & $40-1,15-17$ & .50 & $M-P$ & & & & & & .20 & 1.0 & 1.4 & & - & R & & $R$ & - & $R$ & c & C $c$ & & $R$ & $\mathrm{R}$ & & $c$ & & & - \\
\hline & & $40-7,18-20$ & 2.5 & M & & & & & & 12 & 2.2 & 3.9 & & - & $R$ & & r & - & F & $c$ & C C & $R$ & R & $r$ & R & $c$ & & & - \\
\hline
\end{tabular}

Note: Symbols as for Table 1.

tively drawn between Samples 499-19-3, 110-112 cm and 499-19-6, 10-12 cm (Table 7).

In Sample 499-23-1, 30-83 cm, there is a red-streaked, gray siliceous mud that stratigraphically comprises the entire upper Miocene. Three samples from this unit are tabulated in Table 8. Percentage abundances clearly show the morphotypic top of Diartus petterssoni, the morphotypic top of Didymocyrtis laticonus, the transition of Didymocyrtis antepenultima to D. penultima, and decreasing numbers of Stichocorys delmontensis while $S$. peregrina increases in preparation for that transition.

Lower in that section, Samples 499-23-1, 102-104 cm and $499-23$, CC $(10-12 \mathrm{~cm})$ are clearly from the Dorcadospyris alata Zone, based on the relative abundance of $D$. alata and $D$. dentata. That transition marks the top of the Calocycletta costata Zone between Samples $499-23, \mathrm{CC}(10-12 \mathrm{~cm})$ and $499-24-1,16-18 \mathrm{~cm}$. The earliest occurrence of $C$. costata, between Samples 499$25-3,100-102 \mathrm{~cm}$ and 499-25-4, 102-104 cm indicates the bottom of that zone and the top of the Stichocorys wolffii Zone. Relative abundances for these and other Miocene radiolarians are recorded in Table 9.

Hole 499B was washed to a sub-bottom depth of 201 meters, the level of Core 499-23. The first core catcher showed three lithologies. The uppermost, a light-colored coarse layer, contains a mixed assemblage of about $25 \%$ upper Miocene Didymocyrtis antepenultima Zone and about $75 \%$ middle Miocene Dorcadospyris alata Zone. A sample from the dark green gray mud at 9 to 11 $\mathrm{cm}$ has a good assemblage from the $D$. antepenultima
Zone, with a very small number of middle or lower Miocene species. The light nannofossil ooze at the bottom contains an assemblage from the $D$. alata Zone. Samples 499B-2-1, 80-82 cm and 499B-3-1, 0-1 cm are assigned to the Calocycletta costata Zone on the presence of Dorcadospyris dentata, Eucyrtidium diaphanes, and greater numbers of Liriospyris stauropora than its descendant $L$. parkerae. In Sample 499B-3-4, 48-50 cm, the absence of $C$. costata, $D$. dentata, and $L$. stauropora, and the presence of Lychnocanoma elongata and abundance of Stichocorys wolffii, indicate the lower Miocene S. wolffii Zone. Samples 499B-4-1, 67-69 cm and 499B-6-1, 58-60 cm are evidently below the lowest occurrence of $S$. wolffii and contain greater numbers of Didymocyrtis tubaria than $D$. violina, so they are assigned to the Stichocorys delmontensis Zone. No samples from Cores 499B-5 or -7 were examined, and Cores 499B-8 and -9 are barren of radiolarians. This termination of radiolarian occurrences in the $S$. delmontensis Zone, followed by a barren interval and then basalt, corresponds to the oceanic reference Site 495 .

\section{SITE 500}

Site 500 is at the base of the Middle America Trench landward slope, at the junction of the slope and the Trench floor. The lithology and radiolarian stratigraphy is similar to that of Sites 499 and 495.

Radiolarians are moderately well preserved and diluted with terrigenous debris in Quaternary Cores 500-1 
Table 6. Pliocene to Quaternary radiolarians at Site 497.

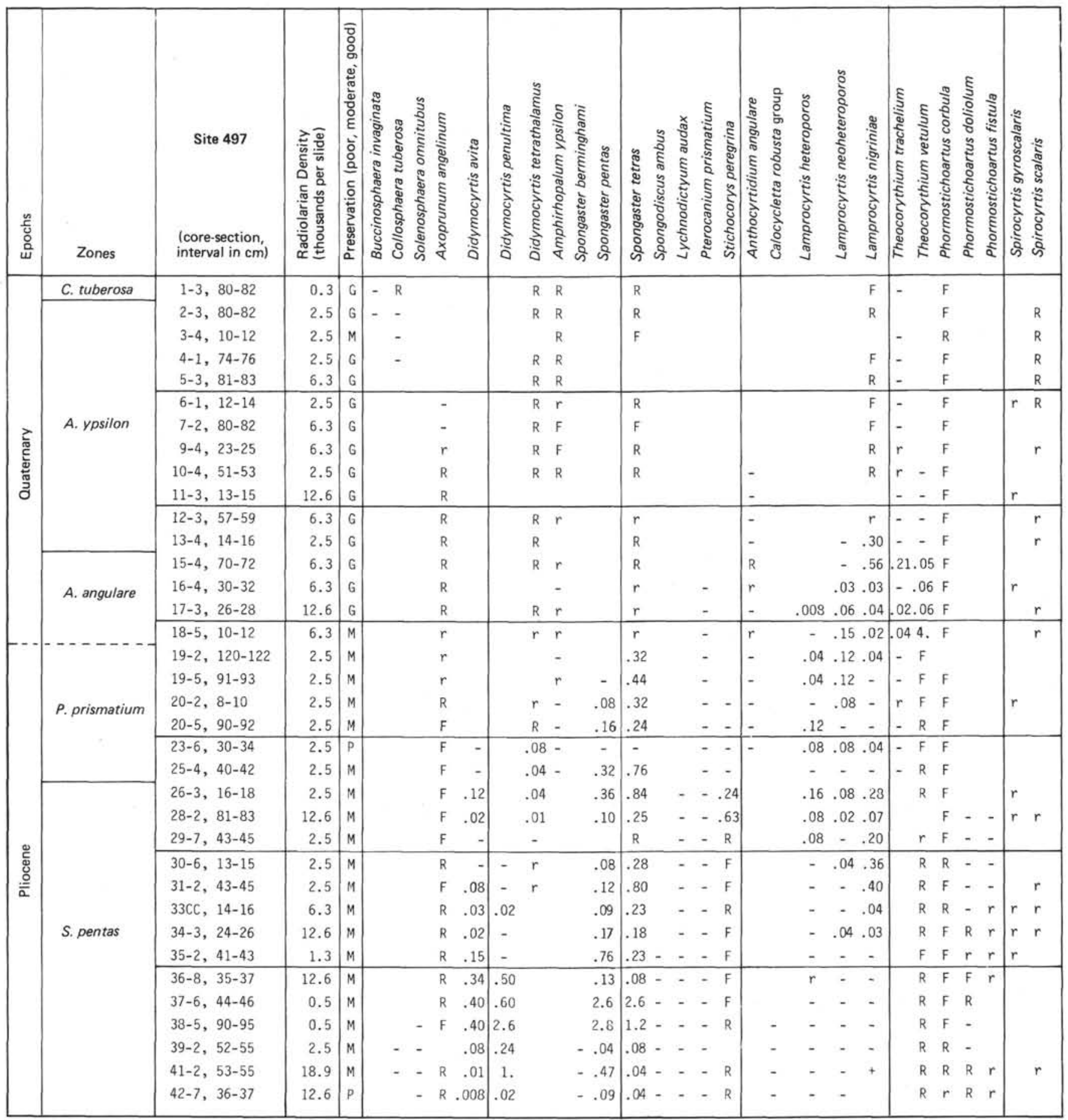

Note: Symbols as for Table 1.

through -10 , and in core catchers from Cores 500A-1 and $\mathbf{- 2}$. Relative abundances are tabulated in Table 10.

There is a contact between Quaternary trench turbidites and middle Miocene foraminifer-nannofossil ooze in Section 500-10-2, and the sediments below that contain radiolarian assemblages corresponding to those of the early and middle Miocene of Site 499 (Table 11). Samples from Cores 500-13 and -14 are placed in the Stichocorys delmontensis Zone. These assemblages appear better-preserved than those of the corresponding cores at Sites 499 and 495 , and diatoms are far more abundant in strewn slides. However, just as at Sites 499 and 495 , the remaining cores above basalt are barren of radiolarians.

\section{INTERPRETATIONS}

\section{Reliability of Events}

The correlation of sequences by means of microfossils is commonly plagued by contradictions in the data, 
Table 7. Pliocene to Quaternary radiolarians at Site 499.

\begin{tabular}{|c|c|c|c|c|c|c|c|c|c|c|c|c|c|c|c|c|c|c|c|c|c|c|}
\hline $\begin{array}{l}\frac{n}{U} \\
\text { 므 }\end{array}$ & Zones & $\begin{array}{l}\text { Site } 499 \\
\text { (core-section, } \\
\text { interval in cm) }\end{array}$ & 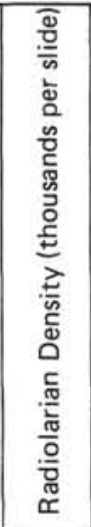 & 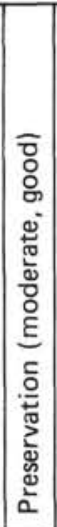 & 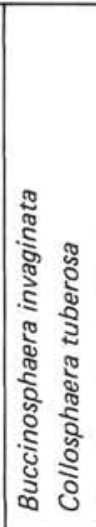 & 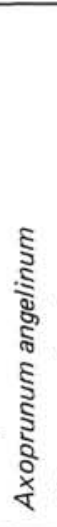 & 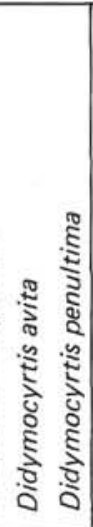 & 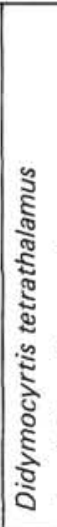 & 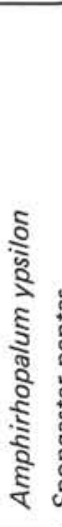 & 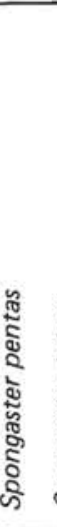 & 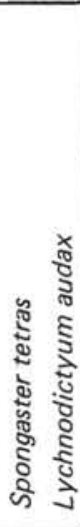 & 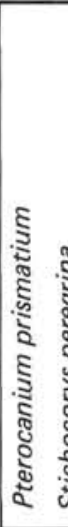 & 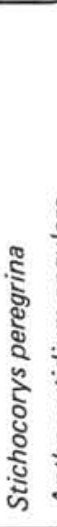 & 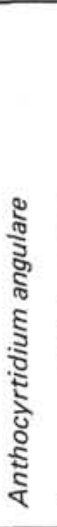 & 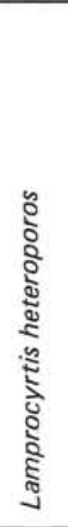 & 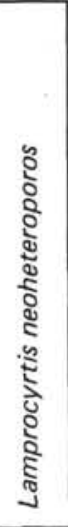 & 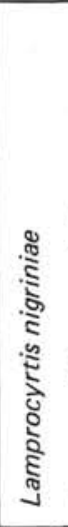 & 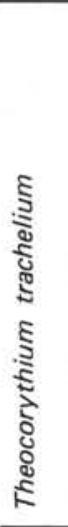 & 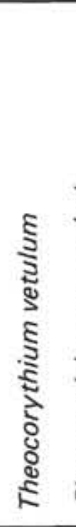 & 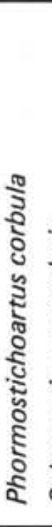 & 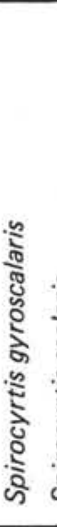 & 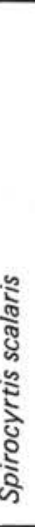 \\
\hline \multirow{18}{*}{ 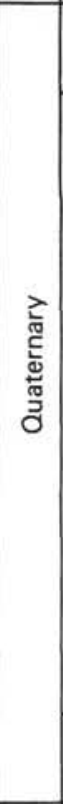 } & C tuheresa & $1-1,106-108$ & 2.5 & $G$ & $-\quad-$ & & $+!$ & $R$ & $R$ & & $r+!$ & & & & $+!$ & & $F$ & $r$ & & $F$ & - & $r$ \\
\hline & C. tader osa & $2-2,109-111$ & 6.3 & G & $-r$ & & & $\mathrm{R}$ & $r$ & & $r$ & & & & & & $R$ & $r$ & & $\mathrm{~F}$ & - & $\mathrm{R}$ \\
\hline & \multirow{14}{*}{ A. ypsilon } & $3-4,144-146$ & .25 & G & -- & - & & $\mathrm{F}$ & $F$ & & $\mathrm{~F}$ & & & & & & $\mathrm{~F}$ & & & $\mathrm{~F}$ & - & $R$ \\
\hline & & $5-3,72-74$ & .25 & G & - & - & & $\mathrm{F}$ & $\mathrm{F}$ & & & & & - & & & $\mathrm{F}$ & & & $\mathrm{F}$ & - & $\mathrm{R}$ \\
\hline & & $6-2,131-136$ & .25 & $\mathrm{G}$ & - & - & & $\mathrm{F}$ & $\mathrm{F}$ & & & & & - & & & $\mathrm{F}$ & & & $\mathrm{F}$ & & \\
\hline & & $7-1,37-39$ & .25 & G & - & - & & & $R$ & & & & & - & & & $R$ & & & $R$ & & \\
\hline & & $9 \mathrm{CC}, 16-18$ & .25 & G & & - & & $\mathrm{R}$ & $R$ & & & & & - & & - & $\mathrm{F}$ & & & R & & \\
\hline & & $10-8,8-10$ & 2.5 & G & & - & & $R$ & $R$ & & & & & - & & - & $\mathrm{R}$ & r & & $R$ & & \\
\hline & & $11-3,41-43$ & .25 & G & & - & & $\mathrm{F}$ & $\mathrm{F}$ & & & & & - & & - & $\mathrm{R}$ & & & $\mathrm{F}$ & & \\
\hline & & $12-3,141-143$ & 6.3 & G & & - & $r ! r !$ & $\mathrm{F}$ & $R$ & & $r$ & & & - & & $r !$ & $\mathrm{F}$ & $r$ & $r !$ & $\mathrm{F}$ & & $r$ \\
\hline & & $13-4,48-50$ & 1.3 & $G$ & & - & & & $R$ & & & & & - & & - & .38 & - & - & $F$ & - & $r$ \\
\hline & & $14-3,37-39$ & 6.3 & G & & - & & $\mathrm{F}$ & $\mathrm{F}$ & & $R$ & & $r !$ & - & & - & .02 & - & - & $\mathrm{F}$ & - & $r$ \\
\hline & & $15-3,102-103$ & 18.9 & G & & $r$ & & $R$ & $R$ & & $\mathrm{R}$ & & & - & & - & .05 & .01 & - & R & $r$ & $r$ \\
\hline & & $16-1,0-3$ & 12.6 & G & & $r$ & $r !$ & $R$ & $R$ & & $r+!$ & & $r !$ & - & & - & .008 & .008 & - & $R$ & & \\
\hline & & $17-3,58-60$ & 18.9 & G & & $r$ & & $\mathrm{R}$ & $R$ & & $r$ & & R! & - & & - & .02 & - & .005 & $R$ & $r$ & \\
\hline & & $17-5,58-60$ & 25.2 & $G$ & & $R$ & $r !$ & $R$ & $F$ & & $\mathrm{R}$ & & $r !$ & - & & - & .04 & .01 & .02 & $R$ & $r$ & $r$ \\
\hline & \multirow{2}{*}{ A. angulare } & $18-1,100-102$ & 6.3 & G & & $F$ & & $R$ & $r$ & & $\mathrm{R}$ & & & $r$ & & .03 & .02 & .05 & .02 & $R$ & & \\
\hline & & $19-3,110-112$ & 12.6 & G & & $\mathrm{F}$ & & $R$ & $r$ & - & $R$ & & & $r$ & & - & .06 & - & - & $\mathrm{F}$ & $r$ & $r$ \\
\hline \multirow{4}{*}{ 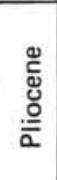 } & \multirow{4}{*}{ P. prismatium } & $19-6,10-12$ & 18.9 & G & & $F$ & & $r$ & + & - & $\mathrm{R}$ & & & - & & - & .03 & .02 & - & $\mathrm{F}$ & $r$ & \\
\hline & & $21-1,45-47$ & 6.3 & M & & $\mathrm{F}$ & & $r$ &.- & 02. & $.05-$ & - & - & - & .03 & .02 & .02 & .02 & .80 & $\mathrm{~F}$ & & 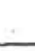 \\
\hline & & $22-1,50-52$ & 18.9 & M & & $F$ & $r$ & $r$ &.- & 04 . & $.05-$ & - & - & - & .01 & .005 & .04 & .005 & .11 & $\mathrm{~F}$ & & \\
\hline & & $22-6,100-102$ & 12.6 & M & & $\mathrm{R}$ & $r r !$ & r & - & 02 . & $.08-$ & - & - & - . & .008 & .008 & - & - & .06 & $F$ & $r$ & r \\
\hline
\end{tabular}

Note: Symbols as for Table 1.

manifested by the crossing of lines connecting the same series of events in several sequences. It becomes necessary, therefore, to judge which of the contradicting lines most likely approximates an isochron. In earlier investigations of DSDP materials, we have routinely used a rather poorly defined scheme of classifying each event in each sequence as stratigraphically "poor," "moderate," or "good" on the basis of the abundance and preservation of each taxon (Riedel and Sanfilippo, 1971, p. 1545). Authors working on non-DSDP materials (Brower et al., 1978; Millendorf et al., 1978) have modified the "relative biostratigraphic value" devised by McCammon (1970), which is based on the proportion of investigated assemblages that contain the species being evaluated, taking account of vertical range, lateral persistence, and facies independence. The first of these procedures (the earlier DSDP investigations) is unsat- isfactory in that the factors involved in evaluating the stratigraphic reliability are too few and not clearly defined; the second (the modified "relative biostratigraphic value" method) also suffers from being oversimplistic. The probabilistic procedures for determining the most likely order of biostratigraphic events (Hay, 1972; Hay and Steinmetz, 1973; Worsley et al., 1973) do not take account of differences in the levels of reliability of particular events at particular sites.

In an attempt to overcome some of these inadequacies, we have elaborated on a concept initiated by a JOIDES panel in order to develop an index of reliability of events that takes account of abundance of the taxon concerned, the extent of our understanding of the evolution of the taxon, the ease of distinguishing it from cooccurring forms, the preservation of the assemblage relative to the susceptibility to solution of the taxon con- 
Table 8. Late Miocene radiolarians at Site 499.

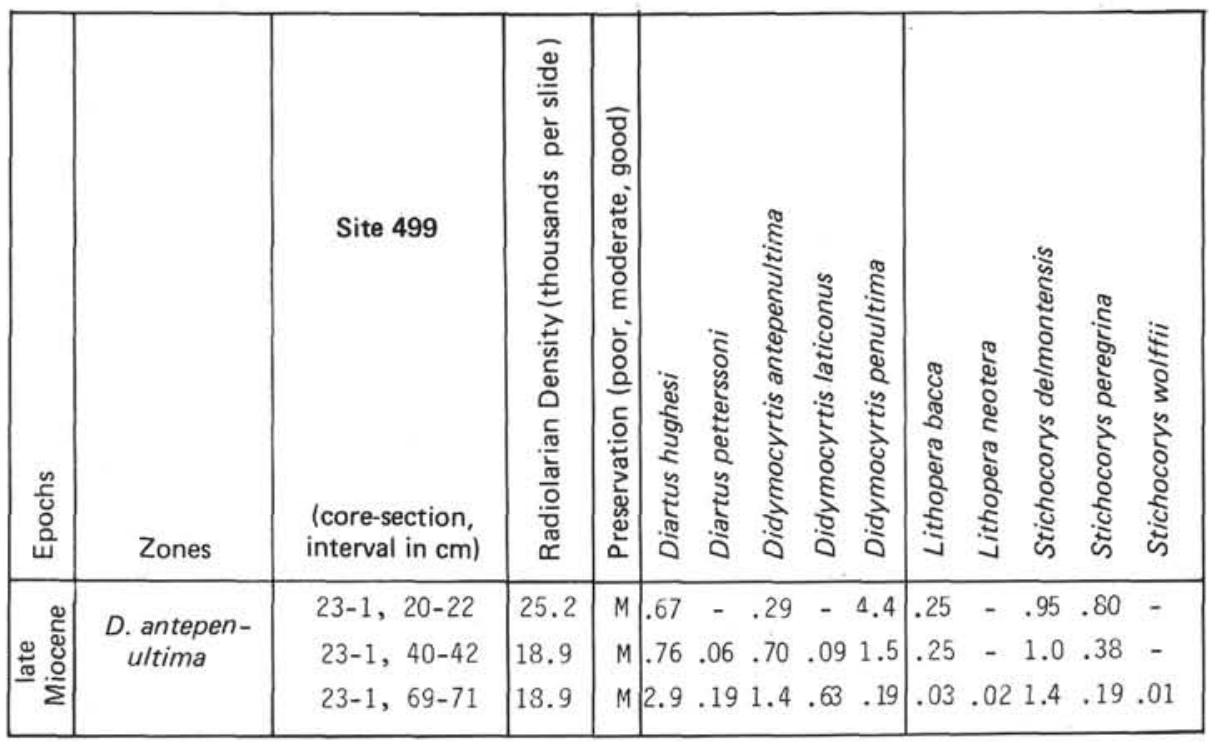

Note: Symbols as for Table 1 .

Table 9. Early to middle radiolarians at Site 499.

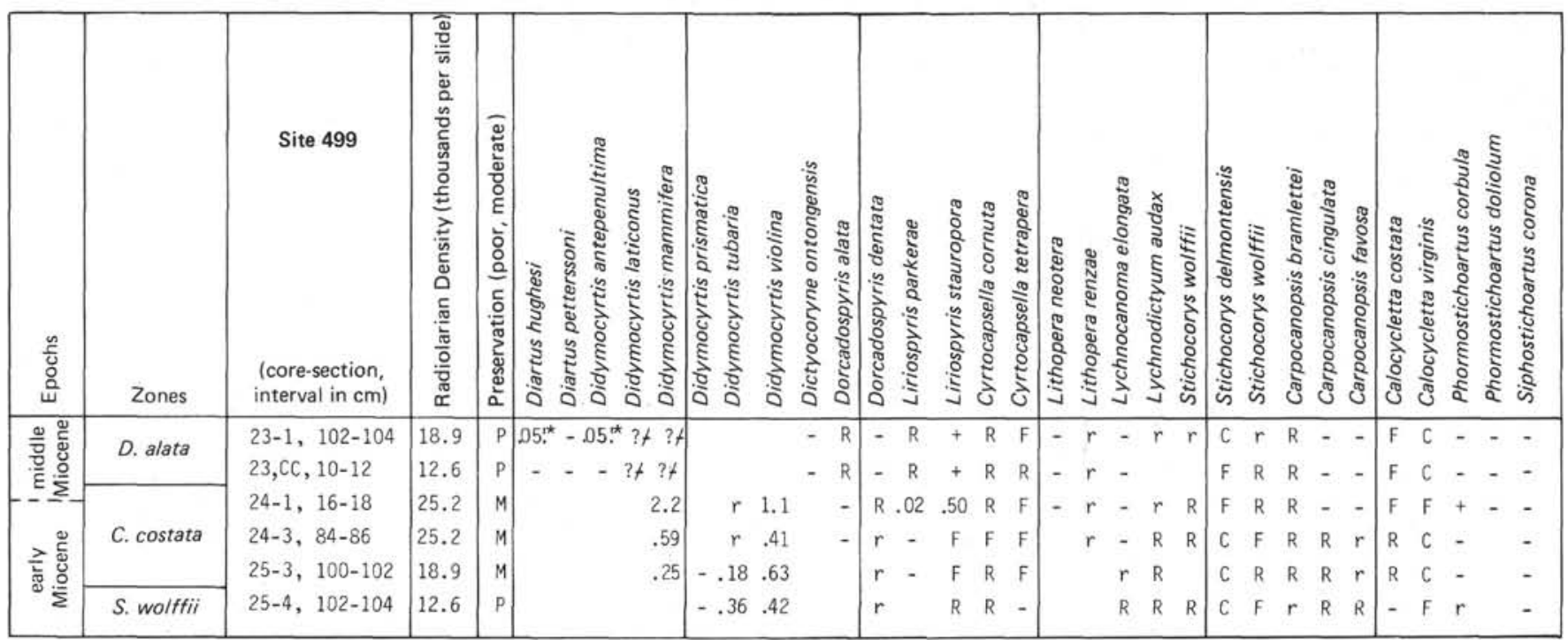

Note: Symbols as for Table $1^{*}=$ probable downworking (this chalky sample had some dark in it). $f=$ relative abundances indeterminate, only cortical shells are preserved.

cerned, low abundances due to dilution, intermittence or constancy of occurrence of the taxon in the sequence, the relation of the locality to the periphery of the area of distribution of the taxon, and the effects of reworking. Some of these factors are numerical, and all are placed arbitrarily on a numerical scale of values $0.1,0.25,0.5$, 0.75 , and 1 (Table 12).

In applying this procedure here for the first time, we find the following explanations of the factors necessary.

A) Abundance of taxon is divided into three ranges, as indicated in Table 12. This refers not to relative abundance but to the absolute number of specimens of the taxon found in the samples near the limits of the stratigraphic range. The purpose is to reflect the greater likelihood of having found the true stratigraphic limit if more than five specimens have been observed in each sample.

B) Average relative abundances of ancestor and descendant above and below evolutionary transitions. For example, if the descendant is 6 times as abundant as the ancestor above the event, and the ancestor is 1.5 times as abundant as the descendant below the event, the average is slightly less than 4 , and would score 0.75 .

C) Type of event, reflecting whether or not the ancestor or descendant of the taxon concerned is known, and the type of evolutionary interpretation. "Cryptogenetic origin" refers to the earliest occurrence of a taxon for which there are several or no candidate ancestors. An extinction is regarded as "cryptogenetic" when the taxon left no known evolutionary descendant, and "evo- 
Table 10. Quaternary radiolarians at Site 500.

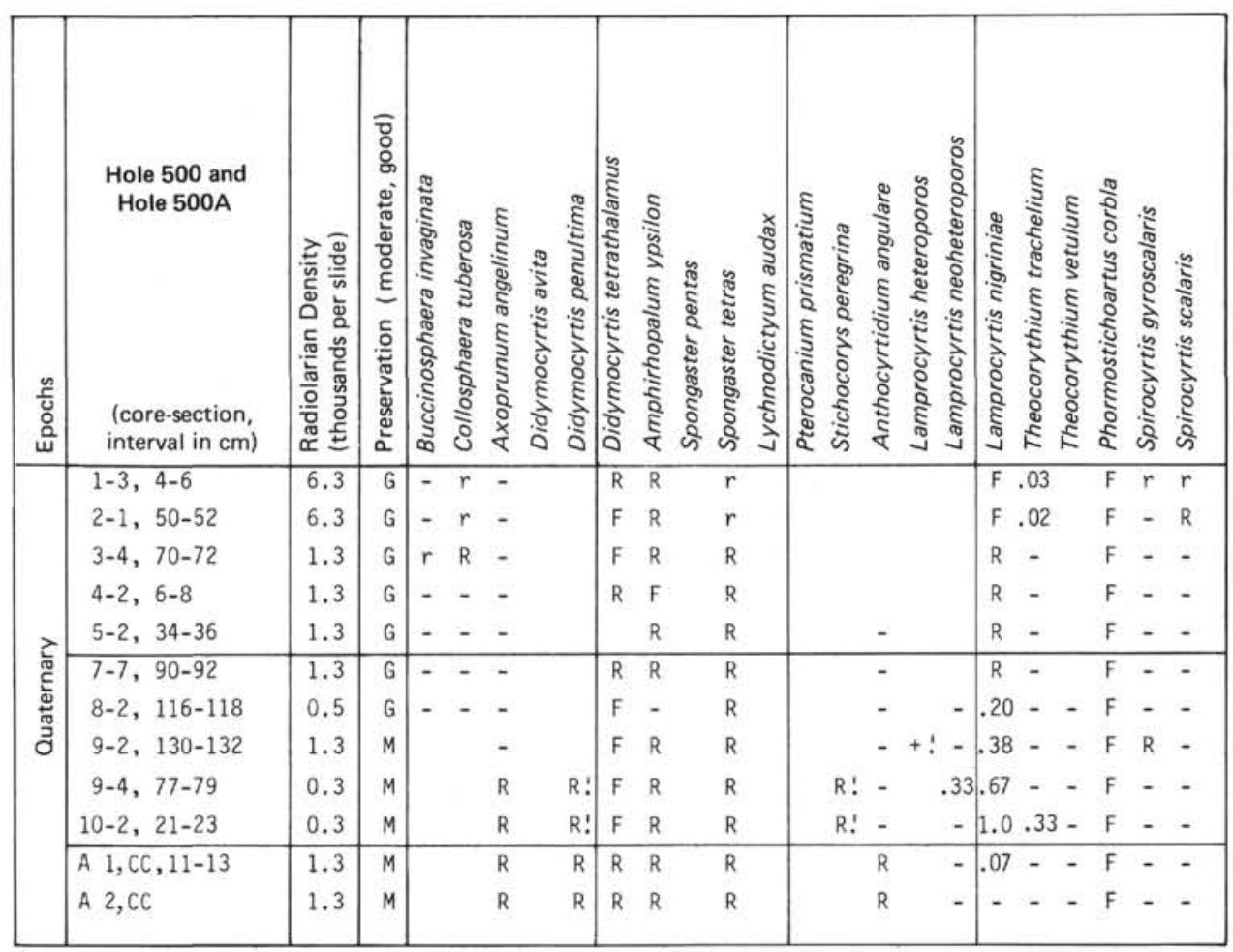

Note: Symbols as for Table 1.

Table 11. Early to middle Miocene radiolarians at Site 500 .

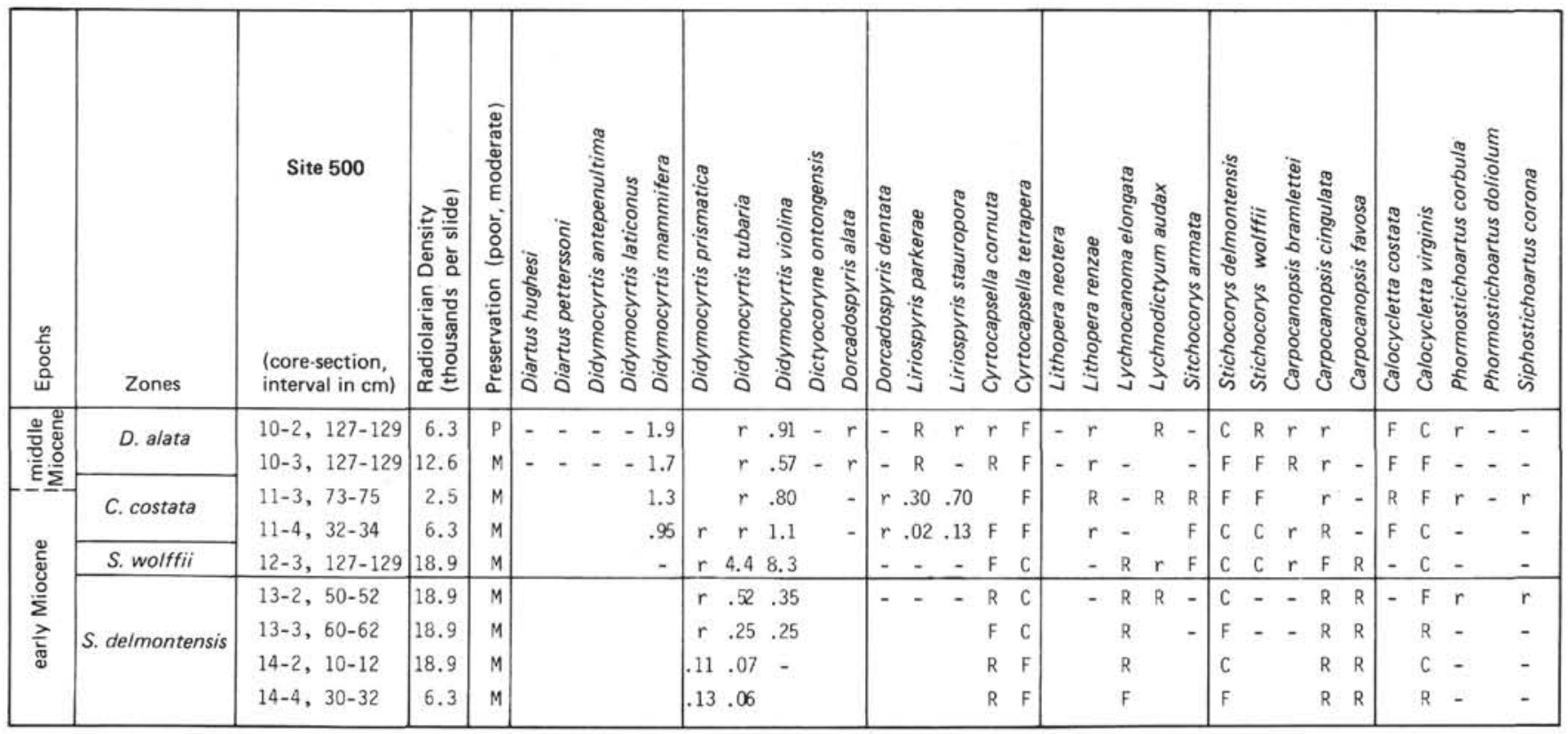

Note: Symbols as for Table 1.

lutionary" when it is confidently interpreted as having terminating its lineage. As with evolutionary extinctions, a score of 0.75 is assigned to morphotypic limits that bracket known evolutionary transitions, as well as to earliest morphotypic occurrences of an evolutionary offshoot from a persistent lineage, because in both of these cases the limit would be extended by searching through much larger samples (Fig. 2). By "evolutionary transition" is meant the level at which the numerical dominance changes from ancestor to descendant.

D) Ease of distinguishing the taxon from co-occurring fossils. The reliability of species distinctions is well known to vary widely, and the scoring of this factor therefore ranges from the minimum value to the max- 
Table 12. Scoring of the value of a particular biostratigraphic event at a particular locality.

\begin{tabular}{|c|c|c|c|c|c|}
\hline Factor $\quad$ Multiplier & 0.10 & 0.25 & 0.50 & 0.75 & 1.00 \\
\hline $\begin{array}{l}\text { A) Abundance of taxon (numbers of speci- } \\
\text { mens observed in each sample) }\end{array}$ & & 1 & $2-5$ & & $>5$ \\
\hline $\begin{array}{l}\text { B) Average relative abundances of } \\
\text { ancestor and descendant above and } \\
\text { below the event (applies only to evolu- } \\
\text { tionary transitions) }\end{array}$ & & & $<2 \times$ & $2-5 \times$ & $>5 \times$ \\
\hline C) Type of event & & & $\begin{array}{l}\text { Cryptogenetic origin } \\
\text { or extinction }\end{array}$ & $\begin{array}{l}\text { Evolutionary extinction, or } \\
\text { morphotypic limit, or } \\
\text { evolutionary offshoot }\end{array}$ & Evolutionary transition \\
\hline $\begin{array}{l}\text { D) Ease of distinguishing the taxon from } \\
\text { co-occurring fossils }\end{array}$ & Difficult & & Moderately easy & & Very easy \\
\hline $\begin{array}{l}\text { E) Is the assemblage well preserved, } \\
\text { relative to the preservation threshold of } \\
\text { the taxon concerned, or are samples } \\
\text { immediately above or below the event } \\
\text { poorly preserved or highly diluted? }\end{array}$ & No & & $\begin{array}{l}\text { Uncertain, or some } \\
\text { difficulty due } \\
\text { to preservation }\end{array}$ & & Yes \\
\hline $\begin{array}{l}\text { F) Constancy of occurrence in the } \\
\text { sequence, above or below the event } \\
\text { (not applicable to evolutionary } \\
\text { transitions) }\end{array}$ & & & & Interrupted & Constant \\
\hline \multirow{2}{*}{$\begin{array}{l}\text { G) Relation of locality to periphery of } \\
\text { area of distribution of taxon } \\
\text { H) Effects of reworking }\end{array}$} & & Near periphery & Unknown & \multirow[b]{2}{*}{$\begin{array}{l}\text { Occurrences outside this } \\
\text { range are certain to be } \\
\text { due to reworking }\end{array}$} & \multirow{2}{*}{$\begin{array}{l}\text { Well within } \\
\text { No reworking }\end{array}$} \\
\hline & \multicolumn{3}{|c|}{$\begin{array}{l}\text { The limit as here interpreted may be unreliable } \\
\text { due to reworking }\end{array}$} & & \\
\hline
\end{tabular}

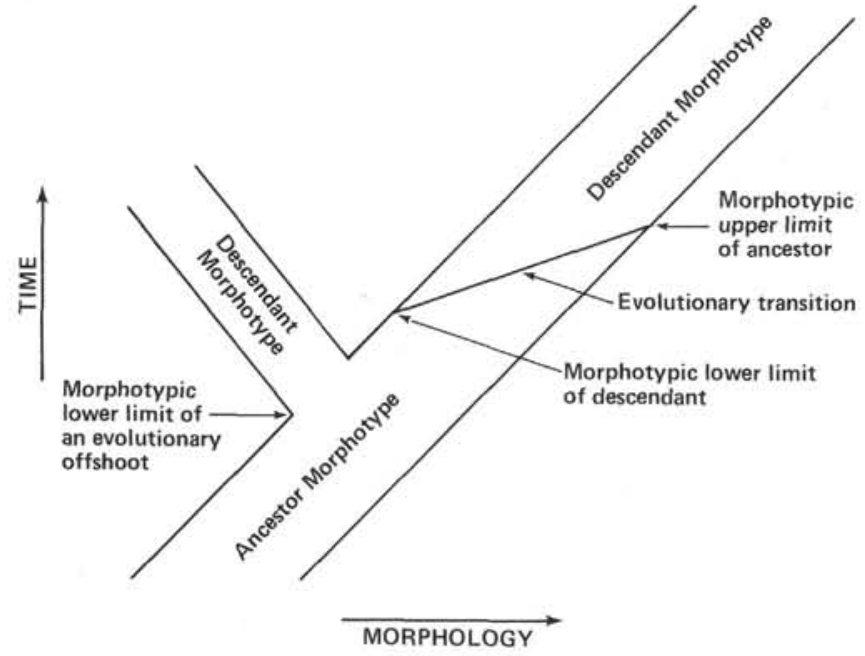

Figure 2. Diagram illustrating the use of terms describing stratigraphic events associated with lineages and evolutionary offshoots.

imum. This is a less objective factor than some others listed.

E) Assemblage preservation relative to the preservation threshold of the taxon concerned. This is clearly a more pertinent factor than an evaluation of the overall preservation of the assemblage. A median score is given when one is uncertain whether an absence or low abundance is due to solution or when solution has removed features necessary for identification from some specimens in the sample.

This category is also used to downgrade the score of an upper morphotypic limit above which (or a lower morphotypic limit below which) absence of the taxon is suspected to be due to dilution or dissolution.
F) Constancy of occurrence in the sequence, within the stratigraphic range of the taxon. This is not applicable to evolutionary transitions because these are located by the changing proportions of ancestor and descendant, not by the limit of range of a morphotype. The need to consider intermittence of occurrence is clearly demonstrated by the highly variable abundances of some rather common species throughout their ranges, as described by Westberg and Riedel (1978).

G) Relation of locality to area of distribution of the taxon. It seems obvious that the earliest and latest records of a taxon near the periphery of its area of distribution will be less reliable stratigraphically than those well within the boundaries. Also, for localities whose relation to biogeographic distributions have changed through time (because of seafloor spreading or changes in oceanic conditions), this factor may be evaluated differently for the upper and lower limits of the same taxon.

H) Effects of reworking. The index of reliability of an event is downgraded slightly if the investigator is confident of having recognized that an extension of stratigraphic range was due to reworking, and is downgraded more if he is less confident. This downgrading is done on the assumption that the reworking is taken into consideration in interpreting the upper or lower limit, and the reworked occurrences are excluded from the range. This is clearly an area of subjective judgment, in which the investigation must take account of sedimentological evidences of disturbance, the abruptness of appearances and disappearances of the taxon in other sequences, evidence of reworking of other taxa into the assemblage, and so on.

As an example of the application of this index, the upper limit of Anthocyrtidium angulare scored 0.5 on each factor A, C, D, E, and G, 0.75 on factor F, and 
1.0 on factor $\mathrm{H}$. Multiplying these together yields 0.02 , which converts to $2 \%$ (the first entry for Site 495 in Table 13).

In designing this index of stratigraphic reliability, we have attempted to formulate a procedure that will be applicable not only to radiolarians but to all microfossil groups. Thus it should be as useful for resolving conflicts between various groups used for stratigraphic correlation, as it is for the various taxa of a single group (see the following section and Riedel and Westberg, in press).

\section{Correlations}

Figure 3 shows the correlations among all of the sites on this Leg. Most of the correlation lines present no problem, but there are two conflicts that the reliability index scores shown in Table 13 help to resolve.

The order of the evolutionary transition from Didymocyrtis violina to D. mammifera, and the morphotypic top of the Carpocanopsis favosa (Events 37 and 38 ) is reversed at Site 499 as compared to Sites 495 and 500 , and although the reliability index for Event 37 is equally low at all three sites, the index for Event 38 at Site 500 is higher than that at Site 499 , indicating that the order at Site 500 is more likely correct.

The morphotypic top of Carpocanopsis cingulata (Event 36 ) at Site 500 occurs above the evolutionary transition from Dorcadospyris dentata to D. alata (Event 34); however, the reliability index for Event 36 at that site is lower than the indices at Sites 495,499 , and 496. Therefore the sequence at these sites is considered the correct one.

\section{Relative Abundances of Families}

Because Sites 494 and 496 are located on the Guatemalan margin and Site 495 is on the Cocos Plate, it is of interest to investigate whether the radiolarian assemblages on the continental side of the Trench differ significantly from those on the oceanic side.

The radiolarian species treated in the main body of this paper were selected (from the much larger total present) because of their known stratigraphic usefulness. It seems appropriate, however, to approach the geographic-environmental question by examining differences in the assemblages at the family level, because this provides a practical means of recording the entire assemblages.

We selected approximately time-equivalent portions of the sequences at the three sites ( $S$. pentas Zone through Quaternary), and assigned 300 specimens from each sample to 14 family categories and the suborder Spyrida. Because we were working at the same time on material from DSDP Leg 68, we gathered the same data on samples from Hole $503 \mathrm{~A}\left(4^{\circ} 03^{\prime} \mathrm{N}, 95^{\circ} 38^{\prime} \mathrm{W}\right)$ for an additional oceanic reference site. Relative percentages are shown in Tables 14 through 17, together with indications of the preservations and the degree of dilution by volcanic ash, diatoms, or other terrigenous materials.

We also compared a data set from a previous publication (Riedel and Sanfilippo, 1978a) as a third example of a non-open-ocean environment. These data are con- stant-numerator percentage estimates of the same 15 family categories in samples from the Pliocene Capo Rossello section in southern Sicily.

These constant-numerator percentage estimates show more details of the contributions of rare taxa to the assemblages but are too time-consuming to apply routinely in preliminary studies such as most of those for DSDP Initial Reports.

After eliminating two families whose abundances were almost always less than $1 \%$, the data from each site were transformed to an $M \times M$ matrix of correlation coefficients between pairs of families, as a first step in the cluster analysis program of Davis (1973, p. 467). The dendrograms of the margin sites show a cluster of four families, spyrids, plagoniids, theoperids, and pterocorythids (Fig. 4). The same families are clustered in the samples from the Sicilian Pliocene, with the addition of cannobotryids and artostrobiids, but no such structure is seen in the dendrograms of the oceanic sites.

Table 18 shows correlation coefficients for some family pairs in all of the sites examined. Nine of the fourteen pairs (rows $1-9$, Table 18 ) have high positive or negative correlation in the margin sites and at Capo Rossello, but insignificant correlations at the open ocean sites. Three pairs (rows 10-12, Table 18) correlate significantly at the margin sites, Capo Rossello, and at Site 495 , but not at Site 503 . Two family pairs (rows 13 and 14 , Table 18) have significant negative correlations at all sites investigated.

These findings represent a substantial advance beyond the tentative indications of covariances resulting from previous work on the Capo Rossello assemblages (Riedel and Sanfilippo, 1978a) and augur well for the possibility of using the relative proportions of high-level radiolarian taxa in order to recognize restricted paleoenvironments.

\section{SPECIES LIST}

The purpose of this list is to provide bibliographic references to the taxa mentioned in this chapter. The only literature references given are to the original description, and to our present concept of the species, if different from or more detailed than the original one.

Alievium superbum (Squinabol)

Theodiscus superbus Squinabol, 1914, p. 271, pl. XX(I), fig. 4.

Alievium superbus (Squinabol), Pessagno, 1972, p. 302, pl. 24, figs. 5, 6, pl. 25, fig. 1 .

Amphipyndax stocki (Campbell and Clark)

Stichocapsa(?) stocki Campbell and Clark, 1944b, p. 44, pl. 8, figs. 31-33.

Amphipyndax stocki (Campbell and Clark), Foreman, 1968, p. 78, pl. 8 , figs. $12 \mathrm{a}-\mathrm{c}$.

Amphirhopalum ypsilon Haeckel

Amphirhopalum ypsilon Haeckel, 1887, p. 522; Nigrini, 1971, p. 447 , pl. 34.1, figs. 7a-c.

Anthocyrtidium angulare Nigrini

Anthocyrtidium angulare Nigrini, 1971, p. 445, pl. 34.1, figs. 3a, b.

Artophormis gracilis Riedel

Artophormis gracilis Riedel, 1959, p. 300, pl. 2, figs. 12, 13.

Axoprunum angelinum (Campbell and Clark)

Stylosphaera angelina Campbell and Clark, 1944a, p. 12, pl. 1, figs. 14-20.

Stylatractus universus Hays, 1970, p. 215, pl. 1, figs. 1, 2.

Axoprunum angelinum (Campbell and Clark), Kling, 1973, p. 634, pl. 1, figs. 13-16, pl. 6 , figs. 14-18. 
Table 13. Radiolarian events at Leg 67 sites.

\begin{tabular}{|c|c|c|c|c|c|c|c|}
\hline \multirow[b]{2}{*}{ Zones } & \multirow[b]{2}{*}{ Events } & \multicolumn{6}{|c|}{ Holes } \\
\hline & & 495 & 499 & 500 & 494 & 497 & 496 \\
\hline C. tuberosa & \multirow{3}{*}{ I Bm C. tuberosa } & \multirow[t]{3}{*}{ - } & $2-2,109-111$ & $3-4,70-72$ & $1-5,59-61$ & $1-3,80-82$ & $1-1,50-52$ \\
\hline \multirow{6}{*}{ A. ypsilon } & & & $3-4,144-146$ & $4-2,6-8$ & $1-6,59-61$ & $2-3,80-82$ & $1-5,50-52$ \\
\hline & & & 7 & 5 & 7 & 12 & 19 \\
\hline & \multirow[t]{3}{*}{$2 \mathrm{Tm}$ A. angelinum } & \multirow[t]{3}{*}{-} & $14-3,37-39$ & $9-2,130-132$ & A2-6, 29-31 & $7-2,80-82$ & $15-4,110-112$ \\
\hline & & & $15-3,102-103$ & $9-4,77-79$ & $\mathrm{~A} 4-1,1-3$ & $9-4,23-25$ & $16-1,30-32$ \\
\hline & & & 75 & 75 & 75 & 75 & 75 \\
\hline & \multirow{3}{*}{$3 \mathrm{Tm} A$. angulare } & $3-6,20-22$ & $17-5,58-60$ & $10-2,21-23$ & - & $13-4,14-16$ & $21-6,86-88$ \\
\hline & & $4-1,75-77$ & $18-1,100-102$ & $\mathrm{Al}, \mathrm{CC}(11-13)$ & & $15-4,70-72$ & $22-4,65-67$ \\
\hline \multirow{10}{*}{ A. angulare } & & 2 & 6 & 3 & \multirow{4}{*}{-} & 5 & 3 \\
\hline & \multirow{3}{*}{$4 \mathrm{Tm} \mathrm{L.} \mathrm{neoheteroporos}$} & $4-1,75-77$ & $17-5,58-60$ & & & $16-4,30-32$ & - \\
\hline & & $4-3,75-77$ & $18-1,100-102$ & & & $17-3,26-28$ & \\
\hline & & 14 & 7 & & & 14 & \\
\hline & \multirow{3}{*}{$\begin{array}{l}5 T . \text { vetulum - } \\
\text { T. trachelium }\end{array}$} & $5-2,40-42$ & $16-1,0-3$ & & - & $15-4,70-72$ & $23-6,30-32$ \\
\hline & & $5-5,40-42$ & $21-1,45-47$ & & & $17-3,26-28$ & $24-3,121-126$ \\
\hline & & 25 & 38 & & & 6 & 9 \\
\hline & $6 \mathrm{Bm} A$. angulare & $6-4,10-12$ & $19-3,110-112$ & & - & $18-5,10-12$ & $23-6,30-32$ \\
\hline & & $6, \mathrm{CC}(3-4)$ & $19-6,10-12$ & & & $19-2,120-122$ & $24-3,121-126$ \\
\hline & & 2 & 6 & & & 5 & 3 \\
\hline & $7 \mathrm{Tm}$ P. prismatium & $\begin{array}{l}7-1,70-72 \\
7-3,70-72\end{array}$ & & & - & - & - \\
\hline prismatium & & 9 & & & & & \\
\hline & $8 \mathrm{Tm} S$. peregrina & $9-3,75-77$ & & & A17-2, 64-66 & $25-4,40-42$ & $26-4,5-7$ \\
\hline & & $9-6,26-28$ & & & A18-1, 90-92 & $26-3,16-18$ & $27-4,29-31$ \\
\hline & & 75 & & & 7 & 75 . & 75 \\
\hline & 9 D. avita $\rightarrow$ & $6-1,92-94$ & & & - & $25-4,40-42$ & $25-4,40-42$ \\
\hline & D. tetrathalamus & $11-1,60-62$ & & & & $26-3,16-18$ & $27-4,29-31$ \\
\hline & & 3 & & & & 3 & 3 \\
\hline & $10 \mathrm{Tm} . L$. audax & $11-1,60-62$ & & & - & - & $26-4,5-7$ \\
\hline & & $\begin{array}{c}11-3,60-62 \\
37\end{array}$ & & & & & $27-4,29-31$ \\
\hline & $11 \mathrm{Tm}$ P. doliolum & $11-3,60-62$ & & & - & $33, \mathrm{CC}(14-16)$ & $26-4,5-7$ \\
\hline & & $11, C C(4-6)$ & & & & $34-3,24-26$ & $27-4,29-31$ \\
\hline & & 19 & & & & 56 & 19 \\
\hline & $12 \mathrm{Bm} P$. prismatium & $11-3,60-62$ & & & - & - & - \\
\hline S. pentas & & $11, \mathrm{CC}(4-6)$ & & & & & \\
\hline & & 14 & & & & & \\
\hline & 13 D. penultima - & $11-3,60-62$ & & & - & $35-2,41-43$ & - \\
\hline & D. avita & $\begin{array}{c}12-3,30-32 \\
4\end{array}$ & & & & $\begin{array}{c}36-8,35-37 \\
9\end{array}$ & \\
\hline & $14 S$. pentas - & $12-7,31-33$ & & & A18-1, 90-92 & $34-3,24-26$ & - \\
\hline & S. tetras & $13-5,54-55$ & & & A $20-2,110-112$ & $35-2,41-43$ & \\
\hline & & 18 & & & 12 & 9 & \\
\hline & $15 \mathrm{Tm}$ S. ambus & $12-7,31-33$ & & & & - & \\
\hline & & $\begin{array}{c}13-5,54-55 \\
9\end{array}$ & & & & & \\
\hline & 16 S. berminghami - & $15-5,30-32$ & & & & - & \\
\hline & S. pentas & $16-2,30-32$ & & & & & \\
\hline & & 38 & & & & & \\
\hline & 17 Tm C. robusta grp. & $\begin{array}{l}15-5,30-32 \\
16-2,30-32\end{array}$ & & & & & \\
\hline & & 50 & & & & & \\
\hline S. peregrina & $18 \mathrm{Bm} \mathrm{S.} \mathrm{ambus}$ & $15-5,30-32$ & & & & & \\
\hline & & $16-2,30-32$ & & & & & \\
\hline & & 9 & & & & & \\
\hline & 19 S. delmontensis - & $15-1,30-32$ & & & & & \\
\hline D. & peregrina & $16-2,30-32$ & & & & & \\
\hline penultima & $20 \mathrm{Tm} D$. hughesi & $16-6,30-32$ & & & & & \\
\hline & & $17-1,30-32$ & & & & & \\
\hline & $21 \mathrm{Tm} D$ antonencie & & & & & & \\
\hline penultima & 21 Im D. ontongensis & $\begin{array}{l}17-6,30-32 \\
18-2,90-92\end{array}$ & & & & & \\
\hline & & 50 & & & & & \\
\hline & 22 D. petterssoni $\rightarrow$ & $17-6,30-32$ & & & & & \\
\hline & D. hughesi & 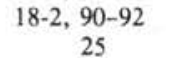 & & & & & \\
\hline & $23 \mathrm{Bm} \mathrm{D.} \mathrm{hughesi}$ & $18-6,101-102$ & & & & & \\
\hline & & $\begin{array}{c}19-1,119-121 \\
38\end{array}$ & & & & & \\
\hline D. & $24 \mathrm{Bm} \mathrm{D}$. ontongensis & $18-6,101-102$ & & & & & \\
\hline petterssoni & & $19-1,119-121$ & & & & & \\
\hline
\end{tabular}


Table 13. (Continued).

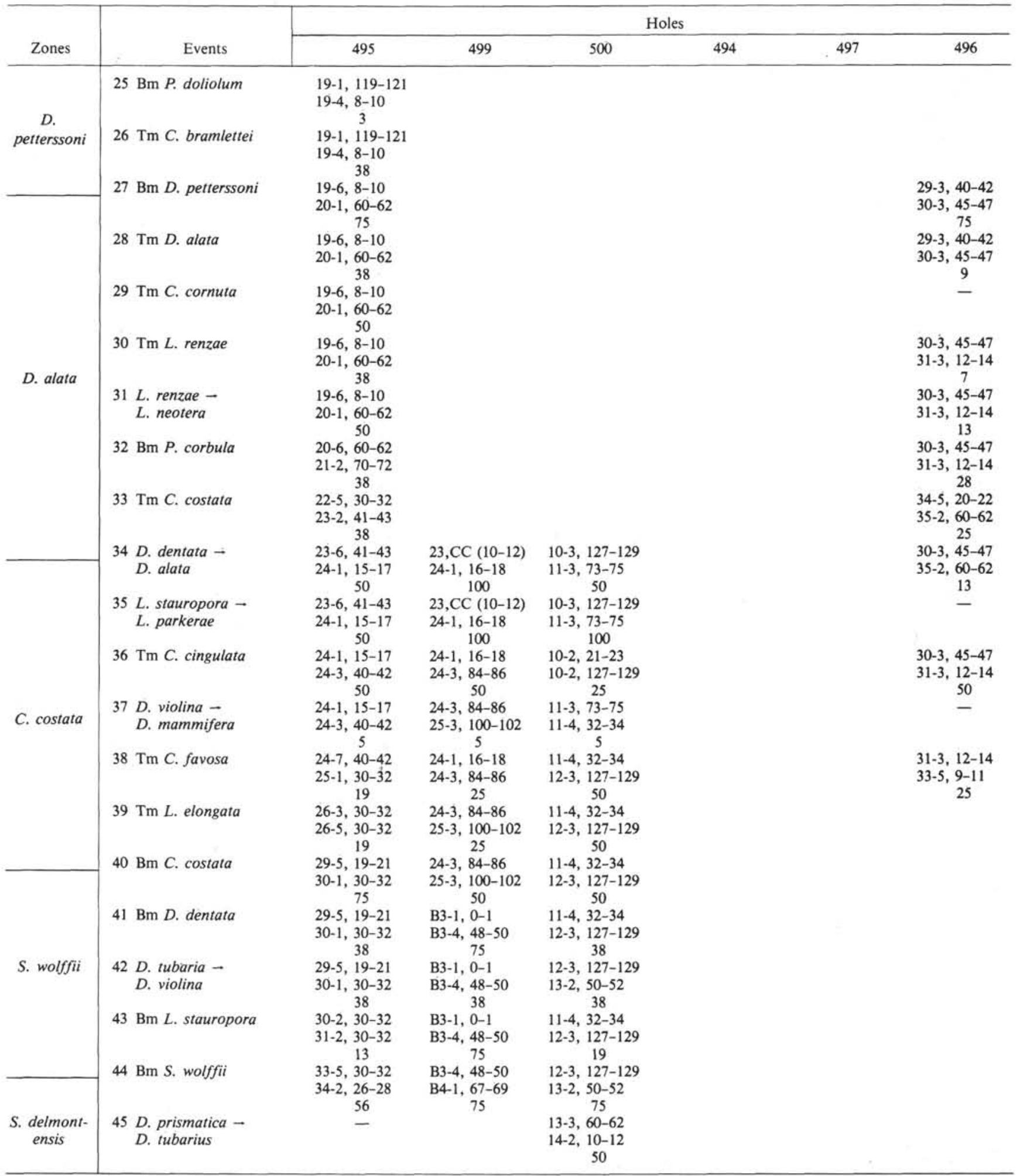

Note: Presented are core-section and intervals in $\mathrm{cm}$ of the samples bracketing the event. The number below the sample numbers indicates the index of reliability (see text). Tm and $\mathrm{Bm}$ indicate the morphotypic top or bottom of a species; arrows indicate evolutionary transitions. 
RADIOLARIANS FROM THE MIDDLE AMERICA TRENCH

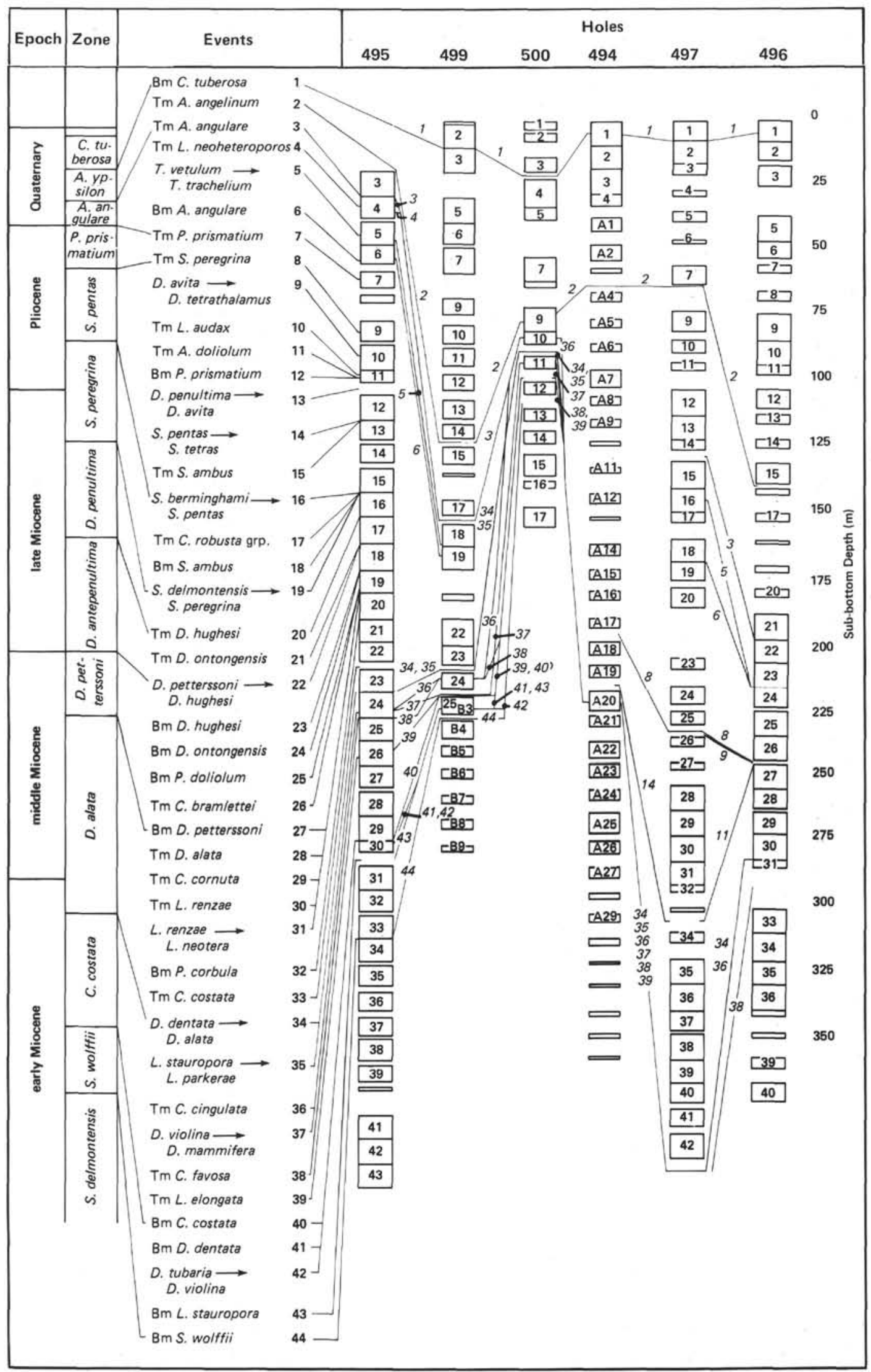

Figure 3. Correlation of radiolarian events in Leg 67 sites. (Each rectangular box represents a core with its number shown inside. Numbers labeling correlation lines correspond to the radiolarian events listed on the left. Tm indicates the morphotypic top of a species and Bm the morphotypic bottom of a species; an arrow denotes evolutionary transitions. Sample intervals bracketing events, and a reliability index for each event, are given in Table 13.) 
Table 14. Percent estimate of radiolarian families and the suborder Spyrida at Site 494.

\begin{tabular}{|c|c|c|c|c|c|c|c|c|c|c|c|c|c|c|c|c|c|c|c|}
\hline $\begin{array}{l}\text { Site } 494 \\
\text { (core-section, } \\
\text { interval in cm) }\end{array}$ & ठั. & 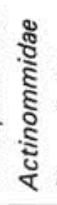 & 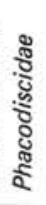 & 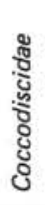 & 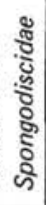 & 离 & ఏః & 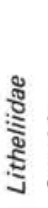 & $\frac{\frac{8}{2}}{\frac{1}{2}}$ & 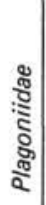 & 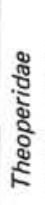 & 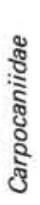 & 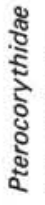 & 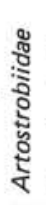 & 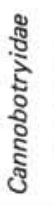 & 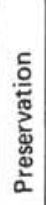 & 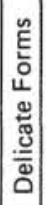 & 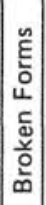 & 喜 \\
\hline $1-1,32-34$ & 3 & 5 & 0 & 5 & 33 & 8 & 0 & 11 & 5 & 5 & 10 & 1 & 9 & 6 & 0 & M & - & $r$ & $50 x$ \\
\hline $2-3,32-34$ & 1 & 10 & 0 & 1 & 36 & 5 & 0 & 12 & 3 & 6 & 9 & 1 & 8 & 5 & 1 & M & - & $r$ & $60 \mathrm{~A}$ \\
\hline $3-2,32-34$ & 3 & 6 & 0 & 1 & 33 & 8 & 0 & 11 & 5 & 4 & 10 & 1 & 9 & 9 & 1 & M & - & $r$ & $50 x$ \\
\hline $4-4,32-34$ & 2 & 8 & 0 & 2 & 35 & 14 & 0 & 11 & 4 & 2 & 10 & 1 & 2 & 8 & 0 & M & - & $r$ & - \\
\hline A $2-6,29-31$ & 5 & 6 & 0 & 1 & 52 & 13 & 0 & 11 & 4 & 2 & 3 & 0 & 2 & 2 & 1 & $M$ & - & $\mathrm{R}$ & $75 x$ \\
\hline A $4-1,1-3$ & 2 & 8 & 0 & 1 & 47 & 12 & 0 & 11 & 5 & 2 & 5 & 1 & 1 & 4 & 0 & $P$ & - & $R$ & $75 x$ \\
\hline A $5-1,60-62$ & 1 & 9 & 0 & 0 & 36 & 9 & 0 & 7 & 3 & 6 & 13 & 3 & 3 & 8 & 2 & $\mathrm{P}$ & - & $R$ & $75 x$ \\
\hline A $7-3,60-62$ & 1 & 3 & 0 & 1 & 41 & 9 & 0 & 5 & 4 & 6 & 13 & 2 & 8 & 6 & 2 & $P$ & - & $R$ & $50 x$ \\
\hline A $8-1,70-72$ & 1 & 6 & 0 & 0 & 46 & 11 & 0 & 13 & 3 & 5 & 5 & 3 & 4 & 2 & 1 & $\mathrm{P}$ & - & $R$ & $80 x$ \\
\hline A $9-1,20-24$ & 1 & 7 & 0 & 1 & 52 & 9 & 0 & 11 & 1 & 3 & 3 & 2 & 3 & 4 & 1 & $P$ & - & $R$ & $90 x$ \\
\hline A $10-1,133-135$ & 1 & 21 & 0 & 0 & 56 & 9 & 0 & 5 & 0 & 0 & 1 & 1 & 2 & 5 & 0 & $P$ & - & $R$ & $99 x$ \\
\hline A $11-1,70-72$ & 1 & 10 & 0 & 2 & 42 & 15 & 1 & 11 & 2 & 4 & 4 & 1 & 2 & 4 & 2 & $\mathrm{P}$ & - & $R$ & $95 x$ \\
\hline A $14-3,12-14$ & 1 & 4 & 0 & 0 & 31 & 11 & 0 & 13 & 6 & 7 & 8 & 1 & 7 & 10 & 1 & M & - & $R$ & $60 D X$ \\
\hline A $16-1,87-91$ & 0 & 9 & 0 & 0 & 59 & 7 & 0 & 9 & 0 & 1 & 4 & 2 & 1 & 7 & 0 & M & - & $\mathrm{R}$ & $50 x$ \\
\hline A $17-2,64-68$ & 0 & 8 & 0 & 0 & 47 & 13 & 0 & 16 & 0 & 1 & 1 & 2 & 2 & 9 & 1 & $M$ & - & $R$ & $95 \mathrm{~A}$ \\
\hline A $18-1,90-92$ & 0 & 12 & 0 & 0 & 52 & 10 & 0 & 16 & 1 & 0 & 1 & 1 & 0 & 5 & 0 & M & - & $R$ & $500 \mathrm{~A}$ \\
\hline A $18-4,64-66$ & 2 & 10 & 0 & 1 & 42 & 9 & 0 & 9 & 2 & 4 & 6 & 2 & 3 & 10 & 1 & M & - & F & $99 x$ \\
\hline A $19-1,7-9$ & 2 & 13 & 0 & 0 & 42 & 11 & 0 & 8 & 2 & 3 & 6 & 1 & 3 & 8 & 1 & M & - & $R$ & $99 x$ \\
\hline A $20-2,110-112$ & 0 & 6 & 0 & 0 & 62 & 15 & 0 & 14 & 0 & 0 & 1 & 0 & 0 & 2 & 1 & M & - & $R$ & $95 x$ \\
\hline A $20-3,75-78$ & 0 & 15 & 0 & 1 & 65 & 4 & 0 & 10 & 0 & 0 & 1 & 0 & 0 & 3 & 1 & M & - & $R$ & $95 x$ \\
\hline
\end{tabular}

Note: In the Preservation column $\mathrm{G}$ indicates good, $\mathrm{M}$ moderate and $\mathrm{P}$ poor. In the next two columns, - indicates none, $r, 0.01-0.1 \%$, and $R, 0.1-1 \%$. The Dilution column indicates the percentage of nonradiolarian components in an average field: $\mathrm{D}$ for diatoms, $\mathrm{A}$ for volcanic ash, and $\mathrm{X}$ for other terrigenous material.

Buccinosphaera invaginata Haeckel

Buccinosphaera invaginata Haeckel, 1887 , p. 99, pl. 5, fig. 11; Strelkov and Reshetnyak, 1962, p. 129 and 137, fig. 12; Nigrini, 1971, p. 445, pl. 34.1, fig. 2; Knoll and Johnson, 1975, p. 63, pl. 1, figs. 3-6.

Calocyclas hispida (Ehrenberg)

Anthocyrtis hispida Ehrenberg, 1873, p. 216.

Calocyclas hispida (Ehrenberg), Riedel and Sanfilippo, 1978b, p. 65 , pl. 3, fig. 6.

Calocycletta costata (Riedel)

Calocyclas costata Riedel, 1959, p. 296, pl. 2, fig. 9; Riedel and Sanfilippo, 1978b, p. 66, pl. 3, fig. 9 .

Calocycletta robusta Moore group

Calocycletta robusta Moore, 1971, p. 743, pl. 10, figs. 5, 6.

Calocycletta caepa Moore, 1972, p. 150, pl. 2, figs. 4-7.

Calocycletta robusta Moore group Riedel and Sanfilippo, 1978b, p. 66 , pl. 3 , figs. 10,11 .

Calocycletta virginis Haeckel

Calocyclas (Calocycletta) virginis Haeckel, 1887, p. 1381, pl. 74, fig. 4.

Calocycletta virginis (Haeckel), Riedel and Sanfilippo, 1978b, p. $66, \mathrm{pl} .3$, figs. 13,14 .

Carpocanopsis bramlettei Riedel and Sanfilippo Carpocanopsis bramlettei Riedel and Sanfilippo, 1971, p. 1597, pl. 2G, figs. $8-14$, pl. 8 , fig. $7 ; 1978$ b, p. 67 , pl. 4, fig. 6 .

Carpocanopsis cingulata Riedel and Sanfilippo

Carpocanopsis cingulata Riedel and Sanfilippo, 1971, p. 1597, pl. $2 \mathrm{G}$, figs. $17-21$, pl. 8 , fig. $8 ; 1978$ b, p. 67 , pl. 4 , fig. 4 .
Carpocanopsis favosa (Haeckel)

Cycladophora favosa Haeckel, 1887, p. 1380, pl. 62, figs. 5, 6. Carpocanopsis favosa (Haeckel), Sanfilippo and Riedel, 1973, p. 531.

Collosphaera tuberosa Haeckel

Collosphaera tuberosa Haeckel, 1887, p. 97; Nigrini, 1971, p. 445, pl. 34.1, fig. 1; Strelkov and Reshetnyak, 1971, p. 336-337, pl. 4, figs. 24, 25; Knoll and Johnson, 1975, p. 63, pl. 2, figs. 1-3.

Cyrtocapsella cornuta Haeckel Cyrtocapsa (Cyrtocapsella) cornuta Haeckel, 1887, p. 1513, pl. 78, fig. 9.

Cyrtocapsella cornuta Haeckel, Riedel and Sanfilippo, 1978b, p. 68 , pl. 4, fig. 17.

Cyrtocapsella tetrapera Haeckel Cyrtocapsa (Cyrtocapsella) tetrapera Haeckel, 1887, p. 1512, pl. 78 , fig. 5.

Cyrtocapsella tetrapera Haeckel, Riedel and Sanfilippo, 1978b, p. 68 , pl. 4 , fig. 18.

Diartus hughesi (Campbell and Clark)

Ommatocampe hughesi Campbell and Clark, 1944a, p. 23, pl. 3, fig. 12.

Ommatartus hughesi (Campbell and Clark), Riedel and Sanfilippo, 1978b, p. 71, pl. 7, fig. 7 .

Diartus hughesi (Campbell and Clark), Sanfilippo and Riedel, 1980 , p. 1010 , text-fig. 1 , i.

Diartus petterssoni (Riedel and Sanfilippo)

Cannartus(?) petterssoni Riedel and Sanfilippo, 1970, p. 520, pl. 14 , fig. 3 ; 1978b, p. 67 , pl. 4 , fig. 2. 
Table 15. Percent estimates of radiolarian families and the suborder Spyrida at Site 496.

\begin{tabular}{|c|c|c|c|c|c|c|c|c|c|c|c|c|c|c|c|c|c|c|c|}
\hline $\begin{array}{l}\text { Site } 496 \\
\text { (core-section, } \\
\text { interval in cm) }\end{array}$ & 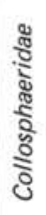 & 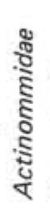 & 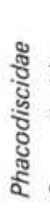 & 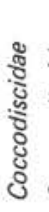 & 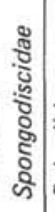 & $\frac{\mathscr{8}}{0}$ & : & : & $\frac{20}{\frac{2}{2}}$ & $\begin{array}{c}\frac{8}{0} \\
: \vdots \\
\vdots \\
\frac{8}{2}\end{array}$ & 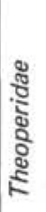 & 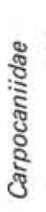 & 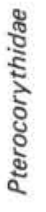 & 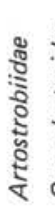 & 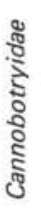 & 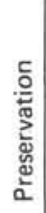 & 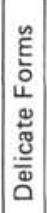 & 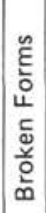 & 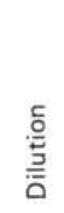 \\
\hline $1-1,50-52$ & 7 & 8 & 0 & 5 & 22 & 8 & 0 & 12 & 5 & 7 & 9 & 1 & 12 & 7 & 0 & G & - & $r$ & $80 x$ \\
\hline $3-4,60-62$ & 1 & 7 & 0 & 3 & 18 & 6 & 0 & 20 & 7 & 7 & 10 & 0 & 12 & 9 & 0 & G & - & $r$ & $60 \times D$ \\
\hline $5-6,117-119$ & 0 & 5 & 0 & 1 & 37 & 7 & 0 & 16 & 3 & 4 & 6 & 0 & 8 & 11 & 1 & G & - & $r$ & $50 x$ \\
\hline $7-2,50-52$ & 3 & 6 & 0 & 3 & 33 & 18 & 0 & 11 & 5 & 2 & 5 & 2 & 9 & 4 & 0 & $M$ & - & r & $50 x$ \\
\hline $9-1,99-101$ & 0 & 5 & 0 & 0 & 20 & 14 & 0 & 14 & 7 & 7 & 12 & 1 & 3 & 11 & 1 & M & - & $r$ & $50 x$ \\
\hline $11-2,60-62$ & 2 & 5 & 0 & 1 & 35 & 13 & 0 & 12 & 6 & 4 & 7 & 0 & 6 & 7 & 2 & M & - & $r$ & $50 x$ \\
\hline $13-1,6-8$ & 6 & 13 & 0 & 0 & 25 & 7 & 0 & 11 & 6 & 5 & 8 & 0 & 5 & 13 & 0 & M & - & r & $50 x$ \\
\hline $14-2,6-8$ & 3 & 16 & 0 & 0 & 45 & 4 & 0 & 11 & 1 & 0 & 4 & 1 & 6 & 8 & 0 & M & - & r & $50 x$ \\
\hline $15-4,110-112$ & 3 & 7 & 0 & 3 & 46 & 10 & 0 & 16 & 2 & 1 & 3 & 0 & 4 & 6 & 0 & M & - & $r$ & $70 x$ \\
\hline $16-1,30-32$ & 6 & 6 & 0 & 1 & 29 & 11 & 0 & 12 & 7 & 6 & 7 & 1 & 7 & 6 & 1 & M & - & $r$ & $40 x$ \\
\hline $19-4,41-42$ & 2 & 11 & 0 & 1 & 34 & 8 & 0 & 10 & 6 & 5 & 10 & 0 & 3 & 7 & 1 & M & - & r & $70 x$ \\
\hline $21-6,86-88$ & 0 & 8 & 1 & 3 & 50 & 8 & 0 & 8 & 3 & 1 & 4 & 2 & 3 & 6 & 1 & M & - & r & $80 x$ \\
\hline $22-4,65-67$ & 1 & 10 & 0 & 1 & 50 & 8 & 0 & 15 & 2 & 1 & 3 & 0 & 1 & 4 & 3 & M & - & r & $90 x$ \\
\hline $23-6,30-32$ & 1 & 11 & 0 & 1 & 43 & 6 & 0 & 12 & 3 & 2 & 6 & 1 & 3 & 11 & 0 & $M$ & - & $r$ & $90 x$ \\
\hline $24-3,124-126$ & 1 & 16 & 0 & 0 & 48 & 3 & 1 & 10 & 3 & 1 & 4 & 1 & 3 & 9 & 0 & M & - & r & $90 x$ \\
\hline $25-4,42-42$ & 3 & 24 & 0 & 0 & 48 & 7 & 0 & 9 & 1 & 1 & 2 & 1 & 1 & 4 & 0 & M & 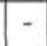 & 1 & $95 x$ \\
\hline $26-4,5-7$ & 7 & 48 & 0 & 4 & 19 & 5 & 0 & 6 & 1 & 0 & 4 & 0 & 2 & 4 & 0 & $\mathrm{P}$ & - & $\mathrm{R}$ & $99 x$ \\
\hline $27-4,29-31$ & 2 & 17 & 1 & 3 & 44 & 5 & 0 & 11 & 1 & 0 & 8 & 1 & 4 & 5 & 0 & M & - & $r$ & $99 x$ \\
\hline $28-3,90-92$ & 4 & 17 & 0 & 3 & 18 & 1 & 1 & 14 & 3 & 6 & 14 & 0 & 4 & 14 & 0 & P & - & $\mathrm{R}$ & $85 x$ \\
\hline
\end{tabular}

Note: See Table 14 for explanations of symbols.

Diartus petterssoni (Riedel and Sanfilippo), Sanfilippo and Riedel, 1980 , p. 1010 , text-fig. 1 , h.

Dictyocoryne ontongensis Riedel and Sanfilippo

Dictyocoryne ontongensis Riedel and Sanfilippo, 1971, p. 1588, pl. 1E, figs. 1, 2, pl. 4, figs. $9-11 ; 1978$ b, p. 68 , pl. 5, fig. 1.

Dictyomitra koslovae Foreman

Dictyomitra koslovae Foreman, 1975, p. 614, pl. 7, fig. 4.

Dictyoprora amphora (Haeckel) group

Dictyocephalus amphora Haeckel, 1887, p. 1305, pl. 62, fig. 4.

Dictyoprora amphora (Haeckel) group Nigrini, 1977, p. 250, pl. 4, figs. $1,2$.

Dictyoprora mongolfieri (Ehrenberg)

Eucyrtidium mongolfieri Ehrenberg, 1854, pl. 36, fig. 18, B lower. Dictyoprora mongolfieri (Ehrenberg), Nigrini, 1977, p. 250, pl. 4, fig. 7.

Dictyoprora urceolus (Haeckel)

Dictyocephalus urceolus Haeckel, 1887, p. 1305.

Dictyoprora urceolus (Haeckel), Nigrini, 1977, p. 251, pl. 4, figs. 9, 10.

Didymocyrtis antepenultima (Riedel and Sanfilippo)

Ommatartus antepenultimus Riedel and Sanfilippo, 1970, p. 521, pl. 14, fig. 4; Westberg and Riedel, 1978, p. 22, pl. 2, figs. 4, 5 . Didymocyrtis antepenultima (Riedel and Sanfilippo), Sanfilippo and Riedel, 1980, p. 1010.

Didymocyrtis avita (Riedel)

Panartus avitus Riedel, 1953, p. 808, pl. 84, fig. 7.

Didymocyrtis avita (Riedel), Sanfilippo and Riedel, 1980, p. 1010.

Didymocyrtis laticonus (Riedel)

Cannartus laticonus Riedel, 1959, p. 291, pl. 1, fig. 5; Westberg and Riedel, 1978, p. 20, pl. 2, figs. 1-3.

Didymocyrtis laticonus (Riedel), Sanfilippo and Riedel, 1980, p. 1010, text-fig. 1, e.

Didymocyrtis mammifera (Haeckel)

Cannartidium mammiferum Haeckel, 1887, p. 375, pl. 39, fig. 16.
Cannartus mammiferus (Haeckel), Riedel, 1959, p. 291, pl. 1, fig. 4 .

Didymocyrtis mammifera (Haeckel), Sanfilippo and Riedel, 1980, p. 1010.

Didymocyrtis penultima (Riedel)

Panarium penultimum Riedel, 1957, p. 76, pl. 1, fig. 1.

Ommatartus penultimus (Riedel), Westberg and Riedel, 1978, p. 22 , pl. 2, figs. 6-8.

Didymocyrtis penultima (Riedel), Sanfilippo and Riedel, 1980, p.

1010 , text-fig. $1, \mathrm{f}$.

Didymocyrtis prismatica (Haeckel)

Pipettella prismatica Haeckel, 1887, p. 305, pl. 39, fig. 6 .

Didymocyrtis prismatica (Haeckel), Sanfilippo and Riedel, 1980, p. 1010 , text-fig. 1 , c.

Didymocyrtis tetrathalamus (Haeckel)

Panartus tetrathalamus Haeckel, 1887, p. 378 , pl. 40, fig. 3 .

Didymocyrtis tetrathalamus (Haeckel), Sanfilippo and Riedel, 1980 , p. 1010 , text-fig. 1 , g.

Didymocyrtis tubaria (Haeckel)

Pipettaria tubaria Haeckel, 1887 , p. 339 , pl. 39 , fig. 15; Riedel, 1959 , p. 289 , pl. 1, fig. 2.

Didymocyrtis tubaria (Haeckel), Sanfilippo and Riedel, 1980, p. 1010.

Didymocyrtis violina (Haeckel)

Cannartus violina Haeckel, 1887, p. 358, pl. 39, fig. 10; Riedel, 1959 , p. 290 , pl. 1 , fig. 3.

Didymocyrtis violina (Haeckel), Sanfilippo and Riedel, 1980, p. 1010, text-fig. 1 , d.

Dorcadospyris alata (Riedel)

Brachiospyris alata Riedel, 1959, p. 293, pl. 1, figs. 11, 12.

Dorcadospyris alata (Riedel), Riedel and Sanfilippo, 1978b, p. 68, pl. 5, fig. 2.

Dorcadospyris ateuchus (Ehrenberg)

Ceratospyris ateuchus Ehrenberg, 1873, p. 218. 
Table 16. Percent estimates of radiolarian families and the suborder Spyrida at Site 495.

\begin{tabular}{|c|c|c|c|c|c|c|c|c|c|c|c|c|c|c|c|c|c|c|}
\hline $\begin{array}{l}\text { Site } 495 \\
\text { (core-section, } \\
\text { interval in cm) }\end{array}$ & 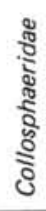 & 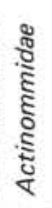 & 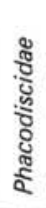 & & 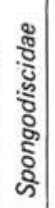 & : &  & : & के & : & 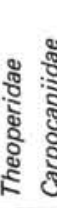 & 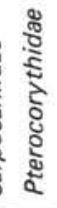 & 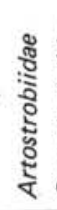 & 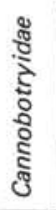 & 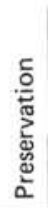 & 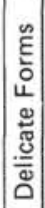 & 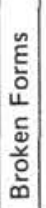 & 돌 \\
\hline $3-1,1-3$ & 2 & 15 & 0 & 5 & 33 & 8 & 0 & 6 & 65 & & 52 & 7 & 5 & 1 & M & - & $R$ & $50 x$ \\
\hline $3-3,60-62$ & 5 & 10 & 0 & 2 & 26 & 8 & 0 & 7 & 53 & 3 & 71 & 14 & 12 & 1 & M & - & $r$ & - \\
\hline $4-1,75-77$ & 4 & 10 & 0 & 0 & 35 & 11 & 1 & 5 & 58 & 81 & 102 & 4 & 4 & 1 & M & $r$ & $r$ & - \\
\hline $4-3,75-77$ & 2 & 6 & 0 & 2 & 34 & 4 & 0 & $10 \%$ & 71 & 0 & 82 & 6 & 7 & 2 & M & - & $r$ & $25 D$ \\
\hline $5-2,40-42$ & 1 & 12 & 0 & 2 & 37 & 7 & 0 & 11 & 65 & 5 & 62 & 1 & 8 & 1 & M & - & $r$ & $50 x$ \\
\hline $5-5,40-42$ & 0 & 13 & 0 & 1 & 55 & 4 & 0 & 8 & 33 & 3 & 41 & 3 & 6 & 0 & $M$ & - & $R$ & $50 x$ \\
\hline $6-4,10-12$ & 8 & 29 & 0 & 1 & 33 & 4 & 0 & 4 & 21 & 1 & 51 & 3 & 8 & 1 & M & - & $R$ & - \\
\hline $7-1,70-72$ & 1 & 17 & 3 & 1 & 23 & 10 & 0 & 7 & 75 & 5 & 63 & 4 & 13 & 1 & M & - & $R$ & $25 x$ \\
\hline $7-3,70-72$ & 1 & 26 & 0 & 0 & 34 & 8 & 0 & 5 & 41 & 1 & $\begin{array}{ll}6 & 1\end{array}$ & 3 & 10 & 0 & M & - & r & - \\
\hline $8-1,16-18$ & 0 & 17 & 0 & 0 & 40 & 7 & 0 & 7 & 51 & 1 & 43 & 4 & 11 & 2 & M & - & $R$ & - \\
\hline $9-3,75-77$ & 5 & 15 & 0 & 1 & 27 & 6 & 0 & 6 & 63 & 3 & 82 & 9 & 8 & 5 & M & - & $R$ & - \\
\hline $9-6,26-28$ & 2 & 11 & 0 & 1 & 27 & 6 & 0 & 9 & 85 & 5 & 73 & 4 & 15 & 2 & M & - & $R$ & $90 \mathrm{~A}$ \\
\hline $10-4,30-32$ & 0 & 19 & 0 & 1 & 30 & 10 & 0 & $6:$ & 31 & 1 & 81 & 5 & 14 & 1 & M & - & $R$ & - \\
\hline $10-6,30-32$ & 0 & 22 & 0 & 1 & 24 & 9 & 0 & 14 & 23 & 3 & 81 & 2 & 13 & 0 & M & - & $R$ & - \\
\hline $11-3,60-62$ & 3 & 25 & 1 & 2 & 32 & 9 & 0 & 7 & 51 & 1 & $\begin{array}{ll}6 & 1\end{array}$ & 3 & 6 & 1 & M & - & $R$ & $50 x$ \\
\hline $12-1,30-32$ & 0 & 29 & 0 & 5 & 16 & 8 & 0 & 11 & 11 & 1 & 90 & 5 & 15 & 0 & M & - & $R$ & $25 A$ \\
\hline $12-5,30-32$ & 0 & 32 & 0 & 1 & 27 & 4 & 0 & 5 & 10 & 0 & 70 & 3 & 19 & 0 & M & - & $r$ & - \\
\hline $13-5,54-55$ & 2 & 26 & 0 & 3 & 29 & 6 & 0 & $4:$ & 31 & 1 & 80 & 6 & 11 & 0 & M & - & $R$ & - \\
\hline $14-3,30-32$ & 6 & 18 & 0 & 1 & 31 & 3 & 0 & 4 & 43 & 3 & 80 & 5 & 16 & 0 & M & - & $R$ & $50 D X$ \\
\hline $14-5,30-32$ & 2 & 18 & 1 & 3 & 25 & 6 & 0 & 9 & 83 & 3 & 80 & 4 & 13 & 0 & M & - & $r$ & - \\
\hline $15-3,30-32$ & 1 & 20 & 1 & 3 & 30 & 7 & 0 & 10 & 31 & 1 & 160 & 4 & 4 & 0 & M & - & $r$ & - \\
\hline $15-5,30-32$ & 0 & 19 & 1 & 2 & 21 & 4 & 0 & 14 & 23 & 3 & 141 & 4 & 16 & 0 & M & - & $r$ & - \\
\hline $16-4,30-32$ & 8 & 10 & 2 & 6 & 18 & 4 & 0 & 11 & 76 & & 150 & 3 & 9 & 1 & M & - & $r$ & - \\
\hline
\end{tabular}

Note: See Table 14 for explanations of symbols.

Dorcadospyris ateuchus (Ehrenberg), Riedel and Sanfilippo, 1978 b, p. 68 , pl. 5 , fig. 3 .

Dorcadospyris dentata Haeckel

Dorcadospyris dentata Haeckel, 1887, p. 1040, pl. 85, fig. 6; Riedel and Sanfilippo, 1978 b, p. 68 , pl. 5, fig. 4.

Eucyrtidium diaphanes Sanfilippo and Riedel

Eucyrtidium diaphanes Sanfilippo and Riedel, in Sanfilippo et al., 1973 , p. 221 , pl. 5 , figs. $12-14$

Eucyrtis micropora (Squinabol)

Archicapsa micropora Squinabol, 1903, p. 129, pl. 9, fig. 14.

Eucyrtis micropora (Squinabol), Foreman, 1975, p. 615, pl. 2I, figs. $2-5$.

Lamprocyrtis heteroporos (Hays)

Lamprocyclas heteroporos Hays, 1965, p. 179, pl. 3, fig. 1.

Lamprocyrtis heteroporos (Hays), Kling, 1973, p. 639, pl. 5, figs. 19-21, pl. 15, fig. 6.

Lamprocyrtis neoheteroporos Kling

Lamprocyrtis neoheteroporos Kling, 1973, p. 639, pl. 5, figs. 17, 18, pl. 15 , figs. 4,5 .

Lamprocyrtis nigriniae (Caulet)

Conarachnium nigriniae Caulet, 1971, p. 3, pl. 3, figs. 1-4, pl. 4, figs. 1-4.

Lamprocyrtis haysi Kling, 1973, p. 639, pl. 5, figs. 15, 16, pl. 15, figs. 1-3.

Lamprocyrtis nigriniae (Caulet), Kling, 1977, p. 217, pl. 1, fig. 17. Eusyringium fistuligerum (Ehrenberg)

Eucyrtidium fistuligerum Ehrenberg, 1873, p. 229.

Eusyringium fistuligerum (Ehrenberg), Riedel and Sanfilippo, 1978 b, p. 68, pl. 5 , figs. 6,7 .
Liriospyris parkerae Riedel and Sanfilippo Liriospyris parkerae Riedel and Sanfilippo, 1971, p. 1590, pl. 2C, fig. 15, pl. 5, fig. 4 .

Liriospyris stauropora (Haeckel)

Trissocyclus stauroporus Haeckel, 1887, p. 987, pl. 83, fig. 5. Liriospyris stauropora (Haeckel), Riedel and Sanfilippo, 1971, p. 1590 , pl. 2C, figs. 16-19.

Lithochytris vespertilio Ehrenberg

Lithochytris vespertilio Ehrenberg, 1873, p. 239; Riedel and Sanfilippo, 1978b, p. 69, pl. 6, fig. 4.

Lithocyclia ocellus Ehrenberg group

Lithocyclia ocellus Ehrenberg, 1854, pl. 36, fig. 30.

Lithocyclia ocellus Ehrenberg group Riedel and Sanfilippo, 1978b, p. 70 , pl. 6 , fig. 8 .

Lithopera bacca Ehrenberg

Lithopera bacca Ehrenberg, 1872, p. 314; Riedel and Sanfilippo, 1978 b, p. 70 , pl. 6 , fig. 9.

Lithopera neotera Sanfilippo and Riedel Lithopera neotera Sanfilippo and Riedel, 1970, p. 454, pl. 1, figs. 24-26, 28; Riedel and Sanfilippo, 1978b, p. 70, pl. 6, fig. 10.

Lithopera renzae Sanfilippo and Riedel

Lithopera renzae Sanfilippo and Riedel, 1970, p. 454, pl. 1, figs. 21-23, 27; Riedel and Sanfilippo, 1978b, p. 70, pl. 6, fig. 11 .

Lophocyrtis biaurita (Ehrenberg)

Eucyrtidium biauritum Ehrenberg, 1873, p. 226.

Lophocyrtis biaurita (Ehrenberg), Haeckel, 1887, p. 1411; Cita et al., 1970, p. 404, pl. 2, I, J, K.

Lychnocanoma elongata (Vinassa)

Tetrahedrina elongata Vinassa, 1900, p. 243, pl. 2, fig. 31. 
Table 17. Percent estimates of radiolarian families and the suborder Spyrida at Site 500.

\begin{tabular}{|c|c|c|c|c|c|c|c|c|c|c|c|c|c|c|c|c|c|c|c|}
\hline $\begin{array}{l}\text { Hole 503A } \\
\text { (core-section, } \\
\text { interval in cm) }\end{array}$ & 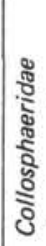 & 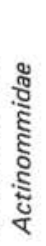 & 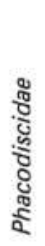 & 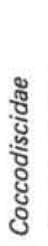 & 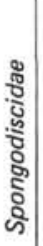 & 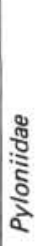 & 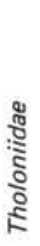 & 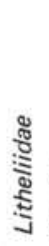 & $\frac{8}{2}$ & 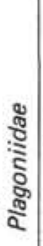 & 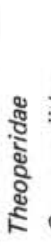 & 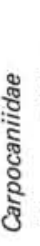 & $\begin{array}{l}8 \\
\text { d } \\
\text { d }\end{array}$ & 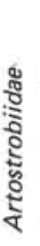 & 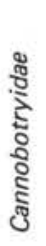 & 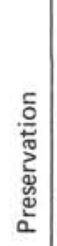 & 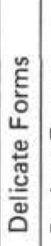 & 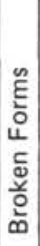 & 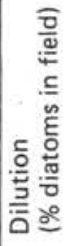 \\
\hline $1-1,50-54$ & 4 & 11 & 1 & 3 & 17 & 14 & 0 & 7 & 4 & 9 & 9 & 0 & 5 & 13 & 2 & M & - & r & 80 \\
\hline $4-1,50-54$ & 2 & 13 & 0 & 3 & 21 & 11 & 0 & 4 & 6 & 7 & 4 & 3 & 7 & 18 & 1 & M & - & $R$ & $<1$ \\
\hline $5-2,50-54$ & 0 & 14 & 0 & 1 & 30 & 5 & 0 & 8 & 6 & 8 & 4 & 1 & 5 & 17 & 1 & M & - & $R$ & $<1$ \\
\hline $7-1,50-54$ & 1 & 10 & 0 & 2 & 45 & 8 & 0 & 9 & 4 & 4 & 1 & 2 & 4 & 9 & 1 & $M$ & - & $R$ & $<1$ \\
\hline $9-1,50-54$ & 4 & 30 & 0 & 0 & 24 & 9 & 0 & 9 & 2 & 2 & 3 & 2 & 4 & 13 & 1 & M & - & $\mathrm{R}$ & $<1$ \\
\hline $10-1,50-54$ & 3 & 18 & 0 & 1 & 21 & 11 & 0 & 9 & 5 & 6 & 4 & 4 & 6 & 10 & 2 & $M$ & - & $r$ & 10 \\
\hline $12-3,50-54$ & 3 & 14 & 0 & 2 & 21 & 12 & 0 & 11 & 4 & 5 & 5 & 4 & 6 & 11 & 2 & M & - & r & 10 \\
\hline $15-2,66-70$ & 6 & 12 & 0 & 1 & 23 & 12 & 0 & 12 & 7 & 4 & 6 & 2 & 3 & 10 & 2 & M & - & $r$ & 10 \\
\hline $19-2,60-64$ & 3 & 9 & 0 & 3 & 20 & 14 & 0 & 8 & 6 & 7 & 11 & 2 & 6 & 8 & 4 & M & - & $r$ & 10 \\
\hline $21-2,50-54$ & 7 & 15 & 0 & 3 & 24 & 7 & 0 & 6 & 4 & 4 & 14 & 2 & 4 & 10 & 0 & M & - & $r$ & 10 \\
\hline $24-3,50-54$ & 2 & 10 & 0 & 3 & 15 & 10 & 0 & 9 & 6 & 11 & 13 & 4 & 4 & 12 & 2 & M & - & $r$ & 10 \\
\hline $29-2,50-54$ & 4 & 16 & 0 & 2 & 17 & 6 & 0 & 5 & 4 & 8 & 19 & 2 & 4 & 12 & 2 & M & - & $r$ & 20 \\
\hline $31-2,50-54$ & 2 & 7 & 0 & 1 & 25 & 6 & 0 & 8 & 3 & 13 & 13 & 1 & 2 & 16 & 1 & M & - & r & 40 \\
\hline $34-3,50-54$ & 5 & 9 & 0 & 1 & 23 & 3 & 0 & 5 & 6 & 16 & 13 & 0 & 5 & 13 & 2 & M & - & r & 80 \\
\hline $36-1,81-84$ & 9 & 10 & 0 & 2 & 24 & 6 & 0 & 6 & 4 & 11 & 15 & $\underline{0}$ & 4 & 9 & 0 & M & - & $r$ & 60 \\
\hline $37-2,50-54$ & 8 & 6 & 0 & 2 & 20 & 11 & 0 & 9 & 7 & 8 & 12 & 0 & 6 & 9 & 3 & M & - & $r$ & 40 \\
\hline $40-1,50-54$ & 17 & 4 & 0 & 1 & 16 & 10 & 0 & 8 & 3 & 9 & 17 & 0 & 4 & 9 & 2 & M & - & $r$ & 60 \\
\hline $42-1,50-54$ & 5 & 9 & 0 & 0 & 14 & 3 & 0 & 4 & 4 & 22 & 19 & 1 & 3 & 11 & 4 & M & - & r & 80 \\
\hline $43-2,50-54$ & 14 & 4 & 0 & 2 & 20 & 4 & 0 & 10 & 5 & 12 & 12 & 1 & 2 & 11 & 4 & M & - & r & 80 \\
\hline $48-2,50-54$ & 7 & 6 & 1 & 2 & 21 & 8 & 0 & 9 & 5 & 7 & 16 & 2 & 2 & 13 & 1 & M & - & $r$ & 10 \\
\hline $49-1,50-54$ & 7 & 5 & 0 & 1 & 19 & 7 & 0 & 6 & 6 & 17 & 13 & 0 & 4 & 12 & 4 & M & - & r & 50 \\
\hline $50-2,50-54$ & 5 & 9 & 0 & 0 & 21 & 5 & 0 & 7 & 7 & 13 & 13 & 1 & 4 & 13 & 1 & $M$ & - & $r$ & 50 \\
\hline $51-1,50-54$ & 16 & 8 & 1 & 0 & 15 & 4 & 0 & 8 & 7 & 11 & 17 & 0 & 3 & 9 & 2 & M & - & $r$ & 20 \\
\hline $52-1,50-54$ & 8 & 10 & 2 & 4 & 14 & 5 & 0 & 5 & 5 & 13 & 15 & 1 & 4 & 11 & 3 & M & - & r & 10 \\
\hline $54-2,50-54$ & 1 & 10 & 1 & 3 & & 7 & 0 & 8 & 5 & 6 & 20 & 1 & 2 & 9 & 3 & $M$ & - & $r$ & $<1$ \\
\hline
\end{tabular}

Note: See Table 14 for explanations of symbols.

Lychnocanoma elongata (Vinassa), Riedel and Sanfilippo, 1978b, p. 70 , pl. 7 , fig. 4 .

Lychnodictyum audax Riedel

Lychnodictyum audax Riedel, 1953, p. 810, pl. 85, fig. 9.

Phormostichoartus corbula (Harting)

Lithocampe corbula Harting, 1863, p. 12, pl. 1, fig. 21.

Phormostichoartus corbula (Harting), Nigrini, 1977, p. 252, pl. 1, fig. 10.

Phormostichoartus doliolum (Riedel and Sanfilippo)

Artostrobium doliolum Riedel and Sanfilippo, 1971, p. 1599, pl.

$1 \mathrm{H}$, figs. 1-3, pl. 8, figs. 14, 15; Westberg and Riedel, 1978, p. 20, pl. 3, figs. 10,11 .

Phormostichoartus doliolum (Riedel and Sanfilippo), Nigrini, 1977 , p. 252,253 , pl. 1, fig. 14.

Phormostichoartus fistula Nigrini

Phormostichoartus fistula Nigrini, 1977, p. 253, pl. 1, figs. 11-13. Podocyrtis mitra Ehrenberg

Podocyrtis mitra Ehrenberg, 1854, pl. 36, fig. B20; Riedel and Sanfilippo, 1978b, p. 72, pl. 8, fig. 7 .

Podocyrtis papalis Ehrenberg

Podocyrtis paplis Ehrenberg, 1847, fig. 2; Riedel and Sanfilippo, 1970 , p. 532, pl. 11, fig. 1.
Pterocanium prismatium Riedel

Pterocanium prismatium Riedel, 1957, p. 87 , pl. 3, figs. 4, 5; Riedel and Sanfilippo, 1978b, p. 72, pl. 9, fig. 1.

Sethochytris triconiscus Haeckel

Sethochytris triconiscus Haeckel, 1887, p. 1239, pl. 57, fig. 13; Riedel and Sanfilippo, 1978b, p. 73, pl. 9, fig. 6.

Siphostichoartus corona (Haeckel)

Cyrtophormis (Acanthocyrtis) corona Haeckel, 1887, p. 1462, pl. 77 , fig. 15.

Phormostichoartus corona (Haeckel), Riedel and Sanfilippo, 1978b, p. 71, pl. 7, fig. 12 .

Siphostichoartus corona (Haeckel), Nigrini, 1977, p. 257, pl. 2, figs. 5-7.

Solenosphaera omnitubus Riedel and Sanfilippo

Solenosphaera omnitubus omnitubus Riedel and Sanfilippo, 1971, p. 1586, pl. 1A, fig. 24, pl. 4, figs. 1, 2; 1978b, p. 73, pl. 9, figs. $8,9$.

Spirocyrtis gyroscalaris Nigrini

Spirocyrtis gyroscalaris Nigrini, 1977, p. 258, pl. 2, figs. 10, 11.

Spirocyrtis scalaris Haeckel

Spirocyrtis scalaris Haeckel, 1887, p. 1509, pl. 76, fig. 14; Nigrini, 1977 , p. 259 , pl. 2, figs. $12,13$. 


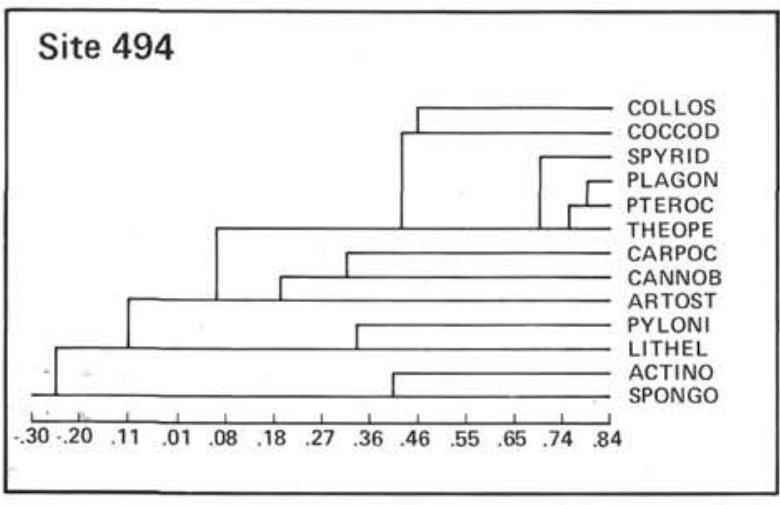

\section{Site 496}

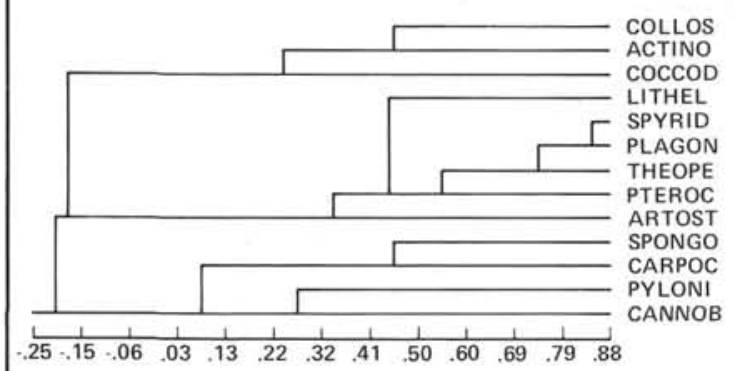

\section{Capo Rossello}

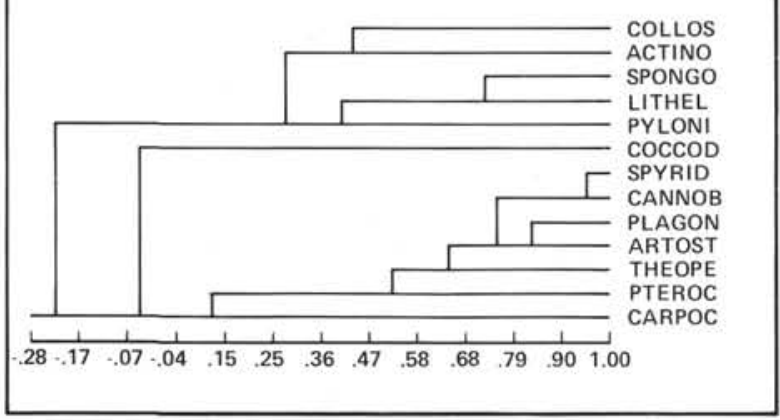

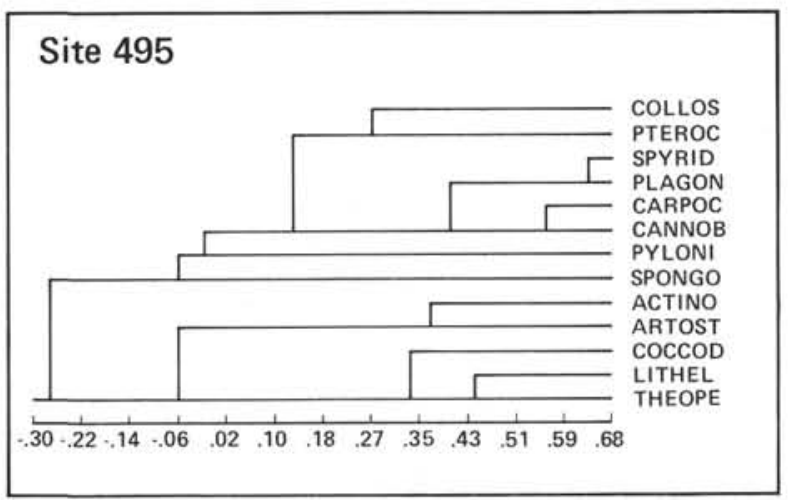

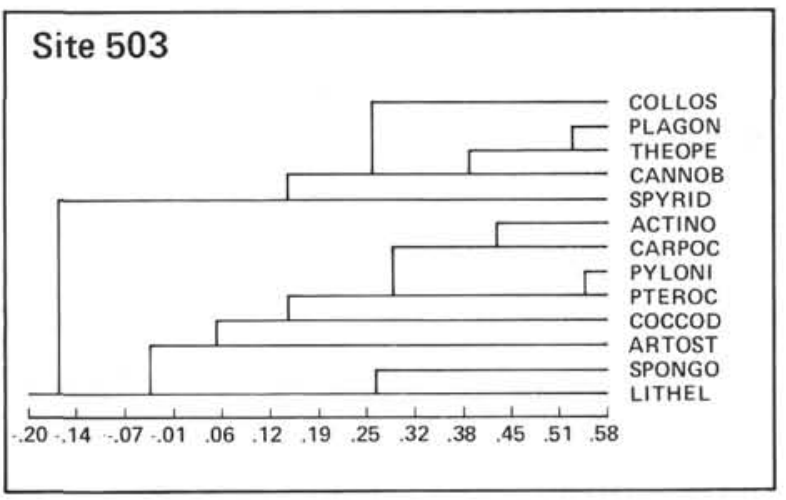

Figure 4. Dendrograms showing family clusters at margin Sites 494 and 496, Capo Rossello, and at oceanic Sites 495 and 503 . (Values on the horizontal axis are similarities.)

Spongaster berminghami (Campbell and Clark)

Spongasteriscus berminghami Campbell and Clark, 1944a, p. 30, pl. 5 , figs. $1,2$.

Spongaster berminghami (Campbell and Clark), Riedel and Sanfilippo, 1978b, p. 73, pl. 2, figs. 14-16.

Spongaster pentas Riedel and Sanfilippo

Spongaster pentas Riedel and Sanfilippo, 1970, p. 523, pl. 15, fig. 3; 1978 b, p. 74, pl. 2, figs. 5-8.

Spongaster tetras Ehrenberg

Spongaster tetras Ehrenberg, 1860, p. 833; Riedel and Sanfilippo, 1978 b, p. 74 , pl. 2, figs. $2,3$.

Spongodiscus ambus Sanfilippo and Riedel

Spongodiscus ambus Sanfilippo and Riedel, 1974, p. 1024, pl. 1, figs. 12-14.

Stichocorys armata (Haeckel)

Cyrtophormis armata Haeckel, 1887, p. 1460, pl. 78, fig. 17. Stichocorys armata (Haeckel), Riedel and Sanfilippo, 1971, p. 1595, pl. 2E, figs. 13-15.
Stichocorys delmontensis (Campbell and Clark)

Eucyrtidium delmontense Campbell and Clark, 1944a, p. 56, pl. 7, figs. 19, 20.

Stichocorys delmontensis (Campbell and Clark), Westberg and Riedel, 1978, p. 22, pl. 3, figs. 1-5.

Stichocorys peregrina (Riedel)

Eucyrtidium elongatum peregrinum Riedel, 1953, p. 812, pl. 85, fig. 2.

Stichocorys peregrina (Riedel), Westberg and Riedel, 1978, p. 22, pl. 3, figs. 6-9.

Stichocorys wolffii Haeckel Stichocorys wolffii Haeckel, 1887, p. 1479, pl. 80, fig. 10; Riedel and Sanfilippo, 1978b, p. 74, pl. 9, fig. 12.

Theocorys spongoconus Kling

Theocorys spongoconus Kling, 1971, p. 1087, pl. 5, fig. 6.

Theocorythium trachelium (Ehrenberg)

Eucyrtidium trachelius Ehrenberg, 1872, p. 312.

Theocorythium trachelium (Ehrenberg), Nigrini, 1967, pp. 77-81, 
Table 18. Correlation coefficients of some family pairs in the Neogene of the eastern tropical Pacific and Sicily.

\begin{tabular}{|c|c|c|c|c|c|}
\hline & \multicolumn{2}{|c|}{$\begin{array}{c}\text { Guatemalan } \\
\text { Margin }\end{array}$} & \multirow[b]{2}{*}{$\begin{array}{c}\text { Capo } \\
\text { Rossello }\end{array}$} & \multicolumn{2}{|c|}{ Open Ocean } \\
\hline & 494 & 496 & & $\begin{array}{c}\text { Cocos } \\
\text { Plate } \\
495\end{array}$ & $\begin{array}{c}\text { East Pacific } \\
\text { Rise } \\
503\end{array}$ \\
\hline 1. Plagoniids/theoperids & +0.8 & +0.8 & +0.6 & +0.2 & +0.5 \\
\hline 2. Plagoniids/pterocorythids & +0.8 & +0.7 & +0.6 & +0.06 & -0.2 \\
\hline 3. Theoperids/pterocorythids & +0.8 & +0.5 & +0.5 & -0.04 & -0.5 \\
\hline 4. Theoperids/spyrids & +0.7 & +0.6 & +0.5 & -0.06 & +0.09 \\
\hline 5. Spyrids/pterocorythids & +0.7 & +0.6 & +0.5 & +0.1 & +0.2 \\
\hline 6. Theoperids/artostrobiids & +0.5 & +0.6 & +0.7 & +0.02 & -0.3 \\
\hline 7. Spongodiscids/spyrids & -0.8 & -0.6 & -0.8 & -0.03 & -0.2 \\
\hline 8. Spongodiscids/plagoniids & -0.8 & -0.7 & -0.9 & +0.02 & -0.5 \\
\hline 9. Spongodiscids/pterocorythids & -0.8 & -0.6 & -0.6 & -0.2 & +0.04 \\
\hline 10. Plagioniids/spyrids & +0.7 & +0.8 & +0.8 & +0.6 & +0.2 \\
\hline 11. Spongodiscids/artostrobiids & -0.6 & -0.4 & -0.8 & -0.5 & +0.06 \\
\hline 12. Actinommids/spyrids & -0.6 & -0.5 & -0.4 & -0.7 & -0.4 \\
\hline 13. Spongodiscids/theoperids & -0.8 & -0.7 & -0.9 & -0.5 & -0.6 \\
\hline 14. Actinommids/plagoniids & -0.5 & -0.5 & -0.5 & -0.8 & -0.6 \\
\hline
\end{tabular}

pl. 8, figs. 1, 2, pl. 9, figs. 1,2 [including subspecies $T$. $t$. dianae]; Riedel and Sanfilippo, 1978b, p. 76, pl. 9, fig. 17.

Theocorythium vetulum Nigrini

Theocorythium vetulum Nigrini, 1971, p. 447, pl. 34.1, figs. 6a, b. Theocotyle cryptocephala (Ehrenberg)

Eucyrtidium cryptocephalum Ehrenberg, 1873, p. 227.

Theocotyle cryptocephala cryptocephala (Ehrenberg), Riedel and Sanfilippo, 1978b, p. 78, pl. 9, fig. 19.

Theocotyle cryptocephala (Ehrenberg), Sanfilippo and Riedel, in press.

Theocyrtis annosa (Riedel)

Phormocyrtis annosa Riedel, 1959, p. 295, pl. 2, fig. 7 .

Theocyrtis annosa (Riedel), Riedel and Sanfilippo, 1978b, p. 78, pl. 10 , fig. 3 .

Thyrsocyrtis (Thyrsocyrtis) bromia Ehrenberg

Thyrsocyrtis bromia Ehrenberg, 1873, p. 260; Riedel and Sanfilippo, 1978b, p. 78, pl. 10, figs. 4, 5 .

Thyrsocyrtis (Thyrsocyrtis) bromia Ehrenberg, Sanfilippo and Riedel, in press.

Thyrsocyrtis (Thyrsocyrtis) rhizodon Ehrenberg

Thyrsocyrtis rhizodon Ehrenberg, 1873, p. 262.

Thyrsocyrtis (Thyrsocyrtis) rhizodon Ehrenberg, Sanfilippo and Riedel, in press.

Thyrsocyrtis (Pentalacorys) triacantha (Ehrenberg)

Podocyrtis triacantha Ehrenberg, 1873, p. 254.

Thyrsocyrtis triacantha (Ehrenberg), Riedel and Sanfilippo, 1978b, p. 82 , pl. 10 , figs. 10,11 .

Thyrsocyrtis (Pentalacorys) triacantha (Ehrenberg), Sanfilippo and Riedel, in press.

\section{ACKNOWLEDGMENTS}

This study was supported by National Science Foundation Grant No. OCE79-20265. We are grateful to K. J. McMillen and Annika Sanfilippo for reviewing the manuscript. M. A. Hanger competently typed the manuscript and assisted with the proofreading. Evelyn Portillo drafted the figures. Alexis Budai and W. Coulbourn advised us on the statistical analysis of the data on abundances of families.

\section{REFERENCES}

Brower, J. C., Millendorf, S. A., and Dyman, T. S., 1978. Methods for the quantification of assemblage zones based on multivariate analysis of weighted and unweighted data. Comput. Geosci., 4: 221-227.

Campbell, A. S., and Clark, B. L., 1944a. Miocene radiolarian faunas from southern California. Geol. Soc. Am. Spec. Pap., 51:1-76. , 1944b. Radiolaria from Upper Cretaceous of Middle California. Geol. Soc. Am. Spec. Pap., 57:1-61.

Caulet, J. P., 1971. Contribution a l'étude de quelques radiolaires nassellaires des boues de la Méditerranée et du Pacifique. Cah. Micropaléontol., Sér. 2(10):1-10.

Cita, M. B., Nigrini, C., and Gartner, S., 1970. Biostratigraphy. In Peterson, M. N. A., Edgar, N. T., et al., Init. Repts. DSDP, 2: Washington (U.S. Govt. Printing Office), 391-411.
Davis, J. C., 1973. Statistics and Data Analysis in Geology: New York (Wiley).

Ehrenberg, C. G., 1847. Über die mikroskopischen kieselschaligen Polycystinen als mächtige Gebirgsmasse von Barbados ünd uber das Verhältnis der aus mehr als $\mathbf{3 0 0}$ neuen Arten bestehenden ganz eigenthümlichen Formengruppe jener Felsmasse zu den lebenden Thieren und zur Kreidebildung. Eine neue Anregung zur Erforschung der Erdlebens. Monatsber. Kgl. Preuss. Akad. Wiss. Berlin Jahrg., pp. 40-60.

1854. Mikrogeologie: Leipzig (Leopold Voss).

1860. Über den Tiefgrund des stillen Oceans zwischen Californien und den Sandwich-Inseln aus bis $15600^{\prime}$ Tiefe nach Lieut. Brooke. Monatsber. Kgl. Preuss. Akad. Wiss. Berlin Jahrg., pp. 819-833.

1872. Mikrogeologischen Studien als Zusammenfassung seiner Beobachtungen des kleinsten Lebens der Meeres-Tiefgrunde aller Zonen und dessen geologischen Einfluss. Monatsber. Kgl. Preuss. Akad. Wiss. Berlin Jahrg., pp. 265-322.

, 1873. Grössere Felsproben des Polycystinen-Mergels von Barbados mit weiteren Erläuterungen. Monatsber. Kgl. Preuss. Akad. Wiss. Berlin Jahrg., pp. 213-263.

Foreman, H. P., 1968. Upper Maestrichtian Radiolaria of California: Special Papers in Palaeontology (No. 3): Palaeontological Association, London, 1-82.

1975. Radiolaria from the North Pacific, Deep Sea Drilling Project, Leg 32. In Larson, R. L., Moberly, R., et al., Init. Repts. DSDP, 32: Washington (U.S. Govt. Printing Office), 579-676.

Haeckel, E., 1887. Report on the Radiolaria collected by H.M.S. Challenger during the years 1873-76. Report on the Scientific Results of the Voyage of the H.M.S. Challenger, Zoology, 18:1-1303.

Harting, P., 1863. Bijdrage tot de kennis der mikroskopische faune en flora van de Banda-Zee, naar aanleiding van een onderzoek van eenige door diepzeeloodingen van 990 tot 4000 vademen uit die zee opgebragte gronden. K. Acad. Wet. Amsterdam Verh., 10:1-34.

Hay, W. W., 1972. Probabilistic stratigraphy. Eclogae Geol. Helv., 65(2):255-266.

Hay, W. W., and Steinmetz, J. C., 1973. Probabilistic analysis of distribution of Late Paleocene-Early Eocene calcareous nannofossils. In Smith, L. A., and Hardenbol, J. (Eds.), Proceedings of Symposium on Calcareous Nannofossils: Houston (Gulf Coast Section, Soc. Econ. Paleontol. Mineral.), pp. 58-70.

Hays, J. D., 1965. Radiolaria and late Tertiary and Quaternary history of Antarctic seas: Biology of the Antarctic Seas. II. Antarct. Res. Ser., 5:125-184.

, 1970. Stratigraphy and evolutionary trends of radiolaria in North Pacific deep sea sediments. In Hays, J. D. (Ed.), Geological Investigations of the North Pacific. Geol. Soc. Am. Mem., 126:185-218.

Hays, J. D., Saito, T., Opdyke, N. D., and Burckle, L. H., 1969. PlioPleistocene sediments of the equatorial Pacific: their paleomag netic, biostratigraphic, and climatic record. Geol. Soc. Am. Bull., 80:1481-1514.

Johnson, D. A., and Knoll, A. H., 1975, Absolute ages of Quaternary radiolarian datum levels in the equatorial Pacific. Quat. Res., 5:99-110.

Kling, S. A., 1971. Radiolaria: Leg 6 of the Deep Sea Drilling Project. In Fischer, A. G., Heezen, B. C., et al., Init. Repts. DSDP, 6: Washington (U.S. Govt. Printing Office), 1069-1117. 1973. Radiolaria from the eastern North Pacific, Deep Sea Drilling Project, Leg 18. In Kulm, L. D., von Huene, R., et al., Init. Repts. DSDP, 18: Washington (U.S. Govt. Printing Office), 617-672.

1977. Local and regional imprints on radiolarian assemblages from California coastal basin sediments. Mar. Micropaleontol., 2(3):207-221.

Knoll, A. H., and Johnson, D. A., 1975. Late Pleistocene evolution of the collosphaerid radiolarian Buccinosphaera invaginata Haeckel. Micropaleontology, 21(1):60-68.

McCammon, R. B., 1970. On estimating the relative biostratigraphic value of fossils. Bull. Geol. Inst. Univ. Uppsala (new series), 2: 49-57.

Millendorf, S. A., Brower, J. C., and Dyman, T. S., 1978. A comparison of methods for the quantification of assemblage zones. Comput. Geosci., 4:229-242. 
Moore, T. C., Jr., 1971. Radiolaria. In Tracey, J. I., Jr., Sutton, G. H., et al., Init. Repts. DSDP, 8: Washington (U.S. Govt. Printing Office), 727-775.

1972. Mid-Tertiary evolution of the radiolarian genus Calocycletta. Micropaleontology, 18:144-152.

Nigrini, C., 1967. Radiolaria in pelagic sediments from the Indian and Atlantic Ocean. Bull. Scripps Inst. Oceanogr., 11:1-125. 1971. Radiolarian zones in the Quaternary of the equatorial Pacific Ocean. In Funnell, B. M., and Riedel, W. R. (Eds.), The Micropalaeontology of the Oceans: Cambridge (Cambridge University Press), pp. 443-461.

1977. Tropical Cenozoic Artostrobiidae (Radiolaria). Micropaleontology, 23(3):241-269.

Pessagno, E. A., 1972. Cretaceous Radiolaria. Part II. Pseudoaulophacidae Riedel from the Cretaceous of California and the BlakeBahama Basin (JOIDES Leg I). Bull. Am. Paleontol., 61(270): 281-328.

Riedel, W. R., 1953. Mesozoic and late Tertiary Radiolaria of Rotti. J. Paleontol., 27:805-813.

, 1957. Radiolaria: a preliminary stratigraphy. Rep. Swed. Deep-Sea Exped., 6:59-96.

1959. Oligocene and Lower Miocene Radiolaria in tropical Pacific sediments. Micropaleontology, 5:285-302.

Riedel, W. R., and Sanfilippo, A., 1970. Radiolaria, Leg 4, Deep Sea Drilling Project. In Bader, R. G., Gerard, R. D., et al., Init. Repts. DSDP, 4: Washington (U.S. Govt. Printing Office), 503-575.

, 1971. Cenozoic Radiolaria from the western tropical Pacific, Leg 7. In Winterer, E. L., Riedel, W. R., et al., Init. Repts. $D S D P$, 7, Pt. 2: Washington (U.S. Govt. Printing Office), $1529-1672$ $81-128$.

, 1978a. Radiolaria. Utrecht Micropaleontol. Bull., 17: 1978b. Stratigraphy and evolution of tropical Cenozoic radiolarians. Micropaleontology, 24(1):61-96.

Riedel, W. R., and Westberg, M. J., in press. Neogene radiolarians from the eastern tropical Pacific and Caribbean, DSDP Leg 68. In Prell, W., and Gardner, J. V., et al., Init. Repts. DSDP, 68: Washington (U.S. Govt. Printing Office).

Sanfilippo, A., Burckle, L. H., Martini, E., and Riedel, W. R., 1973. Radiolarians, diatoms, silicoflagellates and calcareous nanno- fossils in the Mediterranean Neogene. Micropaleontology, 19(2): 209-234.

Sanfilippo, A., and Riedel, W. R., 1970. Post-Eocene "closed" theoperid radiolarians. Micropaleontology, 16(4):446-462.

1973. Cenozoic Radiolaria (exclusive of theoperids, artostrobiids and amphipyndacids) from the Gulf of Mexico, DSDP Leg 10. In Worzel, J. L., Bryant, W., et al., Init. Repts. DSDP, 10: Washington (U.S. Govt. Printing Office), 475-611.

1974. Radiolaria from the West-Central Indian Ocean and Gulf of Aden, DSDP Leg 24. In Fisher, R. L., Bunce, E. T., et al., Init. Repts. DSDP, 24: Washington (U.S. Govt. Printing Office), 997-1035.

1980. A revised generic and suprageneric classification of the Articins (Radiolaria). J. Paleontol., 54(5):1008-1012.

, in press. Revision of the radiolarian genera Theocotyle, Theocotylissa and Thyrsocyrtis. Micropaleontology.

Squinabol, S., 1903. Le Radiolarie dei noduli selciosi nella Scaglia degli Euganei. Contribuzione I. Riv. Ital. Paleontol., 9:105-151.

, 1914. Contributo alla conoscenza dei Radiolarii fossili del Veneto. Appendice-Di un genere di Radiolari caratteristico del secondario. Mem. Ist. Geol. R. Univ. Padova, 2:249-306.

Strelkov, A. A., and Reshetnyak, V. V., 1962. Kolonialnye radiolyarii Spumellaria yuzhno-kitaiskogo morya (raion yuzhoy okonechnosti ostrova Hainan). Stud. Mar. Sin., 1:121-139.

1971. Colonial Spumellarian radiolarians of the world ocean. In Strelkov, A. A. (Ed.), Exploration of the Fauna of the Seas: Moscow (Zoological Institute, Academy of Sciences, U.S.S.R.), IX(XVII):295-373.

Vinassa de Regny, P., 1900. Radiolari miocenici italiani. Mem. $R$. Accad. Sci. Ist. Bologna Ser. 5, 8:227-257.

Westberg, M. J., and Riedel, W. R., 1978. Accuracy of radiolarian correlations in the Pacific Miocene. Micropaleontology, 24(1): $1-23$.

Worsley, T. R., Blechschmidt, G., Ralston, S., and Snow, B., 1973. Probability-based analysis of the area-time distribution of Oligocene calcareous nannofossils. In Smith, L. A., and Hardenbol, J. (Eds.), Proceedings of Symposium on Calcareous Nannofossils: Houston (Gulf Coast Section, Soc. Econ. Paleontol. Mineral.), pp. 71-79. 